\title{
Exploring Smoking, Mental Health and Smoking-related Disease in a Nationally Representative Sample of Older Adults in Ireland: a Retrospective Secondary Analysis
}

\author{
Annette Burns \\ Royal College of Surgeons in Ireland \\ Judith Strawbridge \\ Royal College of Surgeons in Ireland \\ Luke Clancy \\ Technological University Dublin
}

See next page for additional authors

Follow this and additional works at: https://arrow.tudublin.ie/scschbioart

Part of the Biology Commons

\section{Recommended Citation}

Burns A, Strawbridge JD, Clancy L, Doyle F. (2017). Exploring smoking, mental health and smoking-related disease in a nationally representative sample of older adults in Ireland - A retrospective secondary analysis. Journal of Psychosomatic Research98, pp.78-86. doi:10.1016/j.jpsychores.2017.05.005

This Article is brought to you for free and open access by the School of Biological Sciences at ARROW@TU Dublin. It has been accepted for inclusion in Articles by an authorized administrator of ARROW@TU Dublin. For more information, please contact arrow.admin@tudublin.ie, aisling.coyne@tudublin.ie,gerard.connolly@tudublin.ie.

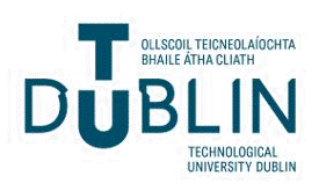


Authors

Annette Burns, Judith Strawbridge, Luke Clancy, and Frank Doyle

This article is available at ARROW@TU Dublin: https://arrow.tudublin.ie/scschbioart/186 
Exploring smoking, mental health and smoking-related disease in a nationally representative sample of older adults in Ireland - a retrospective secondary analysis

Annette Burns $\mathrm{MSc}^{1}$

Judith D Strawbridge PhD²

Luke Clancy PhD ${ }^{3}$

Frank Doyle PhD ${ }^{1}$

${ }^{1}$ Department of Psychology, Royal College of Surgeons in Ireland

${ }^{2}$ School of Pharmacy, Royal College of Surgeons in Ireland

${ }^{3}$ TobaccoFree Research Institute, DIT Kevin Street, Dublin 8

Corresponding author:

Annette Burns

Department of Psychology, Beaux Lane House, Mercer Street Lwr, Royal College of Surgeons in Ireland, Dublin 2.

Phone: 014028622

Fax: 014022764 


\section{Abstract}

Objective: Smoking is the leading preventable cause of death among individuals with mental health difficulties (MHD). The aim of the current study was to determine the impact of smoking on the physical health of older adults with MHD in Ireland and to explore the extent to which smoking mediated or moderated associations between MHD and smoking-related diseases.

Methods: Cross-sectional analysis of a nationally representative sample of 8,175 communitydwelling adults aged 50 and over from The Irish Longitudinal Study on Ageing (TILDA) was undertaken. Multivariate adjusted logistic regression models were used to assess the association between MHD, smoking (current/past/never) and smoking-related diseases (respiratory disease, cardiovascular disease, smoking-related cancers). A number of variables were employed to identify individuals with MHD, including prescribed medication, self-reported diagnoses and self-report scales.

Results: MHD was associated with current (RRRs ranging from 1.84 [1.50 to 2.26] to 4.31 [2.47 to 7.53]) and former (RRRs ranging from 1.26 [1.05 to 1.52] to 1.99 [1.19 to 3.33]) smoking and also associated with the presence of smoking-related disease (ORs ranging from 1.24 [1.01 to 1.51] to 1.62 [1.00 to 2.62]). Smoking did not mediate and rarely moderated associations between MHD and smoking-related disease.

Conclusions: Older adults in Ireland with MHD are more likely to smoke than those without such difficulties. They also experience higher rates of smoking-related disease, although smoking had no mediating and no consistent moderating role in these analyses. Findings underscore the need for attention to the physical health of those with MHD including support in smoking cessation.

Key words: Smoking, Mental Health Disorders, Smoking-related Disease, Older adults, Ireland

\section{Highlights}

- Secondary analysis of a nationally representative sample of older adults in Ireland.

- Examined associations between mental health difficulties (MHD) and smoking and between MHD and smoking-related disease.

- MHD was associated with both smoking and smoking-related disease.

- Smoking did not mediate or consistently moderate associations between MHD and smokingrelated disease.

- Need for attention to the physical health of those with MHD including intensive smoking cessation support. 


\section{Introduction}

\section{Background}

General population smoking prevalence has reached an all-time low of $19 \%$ in the UK and $19.5 \%$ in Ireland ${ }^{1,2}$. Mental health difficulties (MHD) as identified via various indicators including diagnostic or clinical interview, medical records, current psychiatric treatment, reported doctor diagnosed conditions or medication use, are consistently associated with higher smoking prevalences with rates cited ranging from 25.5 to $59 \%^{3-9}$. These increased smoking rates are most pronounced in those with substance use disorders and more severe mental illness (SMI) diagnoses such as bipolar disorder, schizophrenia or psychosis ${ }^{6,7,10-13}$. In general, those with MHD tend to smoke more heavily than other smokers ${ }^{7}$ and also appear to be less likely to quit smoking ${ }^{7}$. While those with schizophrenia appear to be less likely to quit smoking ${ }^{14}$, common mental illnesses such as anxiety or depression also seem to affect quitting behaviour ${ }^{15}$. For instance, meta-analyses have shown that in patients with chronic respiratory conditions or coronary heart disease patients with depressive symptoms are less likely to quit smoking than those without such depressive symptoms ${ }^{16,17}$.

This higher prevalence of smoking has been associated with significant health consequences in those with MHD. People with mental health conditions die on average 10 to 20 years younger than the general population ${ }^{18-22}$ and smoking has been reported as the largest contributor to this premature mortality ${ }^{23,24}$. In the US, Callaghan et al. found significantly heightened patterns of tobacco-related mortality in terms of respiratory disease, smoking-related cancers and cardiovascular disease in patients with schizophrenia (standardised mortality ratio [SMR] 2.45 95\% Cl 2.41-2.48), bipolar disorder (SMR 1.57 95\%Cl 1.53-1.62) and depression (SMR $1.9595 \% \mathrm{Cl}$ 1.93-1.98) ${ }^{25}$. Earlier studies have also shown increased risk of death from cardiovascular disease $4,22,26,27$ and cancer ${ }^{22,26}$. Morbidity studies have also shown those with SMI have a significantly higher prevalence of pulmonary illness ${ }^{3,28-33}$, cancer $^{28}$ and cardiovascular diseases (including stroke, congestive heart failure, angina and myocardial infarction) ${ }^{28-30}$ compared to matched samples or general population counterparts ${ }^{28-32}$. While smoking is thought to account for the majority of morbidity and mortality in these populations, studies have also found associations between mental illness and respiratory disease, cardiovascular disease and risk of death from cardiovascular disease which seems to persist after adjustment for smoking ${ }^{4,28,34}$. However, the literature is limited by the range of conditions investigated, and the samples used are not always generalisable. For example, many of these studies focus on schizophrenia-related disorders and psychosis, though some have also included affective disorder diagnoses ${ }^{28,32}$. Partti et al.'s study of respiratory disease was population-based but only explored psychosis ${ }^{3}$, while other studies were based on clinical populations with some reliant on small samples ranging from 80-100 28,30,32. The last study to address the impact of smoking on the physical health of those with MHD in Ireland is now over 30 years old, was specific to schizophrenia and was not population-based ${ }^{35}$. More generally, morbidity and mortality studies have tended to rely upon one or two indicators, such as structured clinical interviews, medical records, medical service claims or scale scores, but never more than two indicators when identifying those with MHD $3,4,25,27,29,34$. The use of a number of different methods is preferable to enhance the reliability of the findings.

In addition, chronic diseases such as cardiovascular disease and cancers usually occur later in life. Most cancer diagnoses occur in individuals older than 65 years ${ }^{36}$ and CHD risk increases in both men and women after age $55^{37}$. In spite of this, some studies of smoking prevalence in those with MHD 
have been limited to younger samples with age ceilings of 54 and $64^{7,10}$ and there are almost no studies of smoking or smoking-related morbidity or mortality specific to older populations. To our knowledge only one study exploring excess mortality in those with MHD concerns those aged 65 and older ${ }^{27}$. The impact of smoking on the physical health of older adults with MHD therefore remains unclear.

In summary, few population studies have explored smoking-related morbidity in older individuals with MHD and there are no recent studies addressing the health impacts of smoking in those with MHD in Ireland. This study had two aims. Firstly, to determine whether there is a higher prevalence of smoking and of smoking-related disease in older adults with mental health problems. Secondly, to assess whether smoking mediates or moderates the relationship between mental health difficulties and smoking-related disease at a population level. Given the absence of diagnostic interviews, several indicators were used both individually and in combination to reliably identify those with MHD. We hypothesized that persons with MHD would be more likely to have higher levels of smoking-related diseases, which would be explained by a higher rate of smoking.

\section{Methods}

\section{The Irish Longitudinal Study on Ageing (TILDA)}

TILDA provides a stratified clustered nationally representative sample of community dwelling adults aged 50 and over living in Ireland ${ }^{38}$. Private residential dwellings were assigned to clusters stratified by geography and socioeconomic group to produce a population representative sample. Across households where it was possible to make contact to confirm eligibility a response rate of $62 \%$ was achieved ${ }^{39}$. Population weighting was employed to counteract bias introduced by differential nonresponse ${ }^{39}$. The main sample was compared to Quarterly National Household Survey respondents on age, sex and educational attainment and consequent weights assigned ${ }^{38}$. A more detailed description of the study sample and response rates has been described elsewhere ${ }^{40}$. The current analysis involves the first wave which was collected between 2009 and 2011. Data collection involved an extensive face-to- face computer assisted home interview, a self-completion questionnaire for data deemed more sensitive and a health assessment. Health assessments were conducted at TILDA Assessment Centres in Dublin and Cork, or for those not willing to travel to TILDA Assessment Centres a shorter assessment carried out in their home by a qualified, trained nurse was offered. At wave one 5,894 (72.1\%) of the 8,175 participants aged 50 and over completed a health assessment. All variables included in the current analysis were collected at both health centre and home assessments.

\section{Outcomes}

Smoking status: Self-reported current smoking status.

Those who reported ever smoking 'cigarettes, cigars, cigarillos or a pipe daily for a period of at least one year' and answered 'Yes' when asked if they smoked at the present time (including if smoked in past 3 months) were categorised as current smokers. In the initial part of this paper lifetime smoking prevalence (current/former/never) is the outcome, later it was explored as a potential mediator/effect modifier (to achieve the second aim). Smoking status data was available for 8,174 respondents due to the refusal of one participant to answer this question.

Smoking-related disease: The presence of any one or more self-reported doctor diagnosed smoking-related diseases i.e. respiratory disease, cardiovascular disease or smoking-related cancers.

For the purposes of this analysis smoking-related cancer was defined as answering 'Yes' when asked if they were ever told by a doctor that they had cancer in any of the following sites: lung; colon or 
rectum; stomach; oesophagus; bladder; liver; cervix; kidney; pancreas; oral cavity; larynx; other pharynx (including nasopharynx, oropharynx, laryngopharynx or hypopharynx). These sites were identified based on the 2014 Surgeon General's report ${ }^{41}$. Cancer of the lip, the renal pelvis and acute myeloid leukaemia were not included as these were not specified in the TILDA study.

Respiratory disease was defined as answering 'Yes' when asked if they were ever told by a doctor that they had 'chronic lung disease such as chronic bronchitis or emphysema'.

Cardiovascular disease was defined as answering 'Yes' when asked if they were ever told by a doctor that they had 'angina', 'a heart attack (including myocardial infarction or coronary thrombosis)', 'congestive heart failure', 'high cholesterol', 'a stroke (cerebral vascular disease)' or 'Ministroke or TIA'.

Due to low numbers in two categories (respiratory disease $(n=330)$; smoking-related cancers $(n=135))$ all three disease groups were combined to indicate having a chronic smoking-related disease $($ score $=1$ ) or not $($ score $=0$ ) for the purposes of this analysis.

\section{Exposure variables}

MHD: A number of variables were taken as indicators of evidence of MHD and used individually and in combination to model the association between MHD and smoking and between MHD and smoking-related disease.

An emotional, nervous or psychiatric problem was defined as answering 'Yes' when asked if they were ever told by a doctor that they had 'any emotional, nervous or psychiatric problems, such as depression or anxiety".

Alcohol or substance abuse was defined as answering 'Yes' when asked if they were ever told by a doctor that they had an 'alcohol or substance abuse' condition.

Psychiatric medication use: Participants were asked to bring medications to interviewer during the face-to-face home interview and all anxiolytics, antipsychotics and anti-depressants were included (ATC codes: N05B; N05A; N06A). Any participant who was taking one of these medications was considered to have MHD.

Psychometric scales:

CES-D: The Center for Epidemiologic Studies Depression Scale (CES-D) is a 20-item self-report depression scale designed for epidemiological studies of depression ${ }^{42}$. Each item is measured on a 4point Likert scale reflecting frequency of occurrence. A cutoff score of $\geq 16$ is said to indicate clinically significant or severe depressive symptoms while a score of 8-15 is defined as moderate depressive symptoms ${ }^{43-45}$. This measure was administered during the face-to-face computer assisted home interview ${ }^{39}$ and 8,044 (98.4\%) responded to all 20-items.

HADS-A: The HADS-A is the 7-item anxiety subscale of the Hospital Anxiety and Depression Scale ${ }^{46}$. This self-report measure with a four option Likert-type response format was included in the selfcompletion questionnaire and returned by 6,637 of the 8,175 (81.2\%) TILDA participants aged 50 and over. Zigmond and Snaith recommended cutoffs of $>8$ and $>11$ to detect possible and probable anxiety caseness ${ }^{46}$.

For categorical scale variables, the 'probable anxiety' and 'severe depressive symptoms' categories were assessed as indicators of MHD. 


\section{Covariates}

We adjusted for demographic variables (age, sex, education and marital status) when modelling smoking status. In modelling smoking-related disease other known confounders (physical activity, waist circumference, alcohol use and diabetes (self-reported doctor diagnosed)) were also included. Age and waist circumference were continuous, while all other covariates were ordinal/categorical. Physical activity was assessed using the short form 8-item version of The International Physical Activity Questionnaire (IPAQ) ${ }^{47}$, which estimates time spent performing physical activities (moderate to vigorous) as well as inactivity (time spent sitting) ${ }^{48}$. Alcohol problems were identified using the CAGE questionnaire, a widely used and extensively validated screening tool for alcoholism, which was included in the self-completion questionnaire. A CAGE test score of 2 or more is said to identify problem drinkers ${ }^{48,49}$. Waist circumference was measured the health assessment during wave one and so was only available for participants completing that component.

\section{Statistical analyses}

Key variables and demographic characteristics of the sample were compared according to smoking status using analysis of variance models and chi-square statistics as appropriate.

Multinomial regression analysis was performed to investigate the association between MHD and smoking. The models were weighted and adjusted for age, sex, education and marital status as these were all significantly associated with the outcome smoking status. The margins command in Stata provided adjusted prevalence estimates.

Multivariate logistic regression models were then employed to explore the association between MHD and smoking-related disease. These models were weighted and adjusted for potential confounders including socio-demographic characteristics (age, sex, education) and additional known risk factors (physical activity, waist circumference, alcohol use and diabetes (self-reported doctor diagnosed)). These covariates were identified based on the literature.

Baron and Kenny's four step approach was employed to test for mediation ${ }^{50}$. Firstly, as above, we tested to see if the independent variable, MHD, predicted the dependent variable smoking-related disease. Secondly, and also already encompassed in aim one, we tested to see if MHD predicted smoking. Thirdly, it was assessed whether the mediator, smoking status, predicted smoking-related disease even while adjusting for MHD. Finally, smoking status was added to models predicting smoking-related disease and changes in the association between MHD and smoking-related disease were observed for mediation effects.

Then, to test for any moderating role of smoking, interaction terms were also built and added to models.

Data analysis was performed using Stata $13.0^{51}$.

\section{Results}

\section{Sample Description}

This analysis of TILDA included 8,175 participants aged 50 years and over. As described above, due to missing values related to issues such as health assessment attendance and completion of the HADS-A the analytic sample ranged from 5,024 to 8,158 . Sample sizes for each model are included below (Tables 2-4).

Overall $18.24 \%$ of respondents were current smokers and $38.1 \%$ were former smokers. The prevalence of MHD ranged from $1.60 \%$ (self-reported alcohol or substance use problem) to $9.49 \%$ (severe depressive symptoms as per CES-D) based on the various indicator variables. Almost half of respondents (45.9\%) had at least one smoking-related disease at baseline. Cardiovascular disease 
was most prevalent $(43.1 \%)$, followed by respiratory diseases $(4.04 \%)$ and finally smoking-related cancers (1.65\%).

Table 1 illustrates the main characteristics of the sample broken down by current smoking status. Age, sex, education and marital status were all significantly related to current smoking status. Current smokers were younger and more women had never smoked. Overall just $17.3 \%$ of those with a smoking-related disease were current smokers. Over half of those reporting a diagnosed smoking-related cancer were former smokers and almost a third of those reporting diagnosed respiratory conditions were current smokers. 
Table 1

Demographics, physical and mental health and health behaviour characteristics of TILDA cohort $(8,174)$

\begin{tabular}{|c|c|c|c|c|c|c|c|c|}
\hline & \multirow{2}{*}{\multicolumn{2}{|c|}{$\begin{array}{l}\text { Current smoker } \\
(n=1,491) \\
18.2 \%\end{array}$}} & \multicolumn{2}{|c|}{$\begin{array}{l}\text { Former smoker } \\
(n=3,117)\end{array}$} & \multicolumn{4}{|c|}{$\begin{array}{l}\text { Never smoker } \\
(n=3,566)\end{array}$} \\
\hline & & & $38.1 \%$ & & $43.6 \%$ & & & \\
\hline Continuous & Mean & $S D$ & Mean & $S D$ & Mean & $S D$ & $F$ & $p$ Value \\
\hline Age & 61.3 & 8.87 & 64.9 & 9.82 & 64.0 & 9.93 & 69.7 & $<.001^{* *}$ \\
\hline
\end{tabular}

\begin{tabular}{|c|c|c|c|c|c|c|c|c|}
\hline Categorical & $N$ & $\%$ & $N$ & $\%$ & $N$ & $\%$ & $\chi^{2}$ & $p$ Value \\
\hline Women & 811 & $18.3 \%$ & 1,387 & $31.3 \%$ & 2,233 & $50.4 \%$ & 220.0 & $<.001^{* *}$ \\
\hline Men & 680 & $18.2 \%$ & 1,730 & $46.2 \%$ & 1,333 & $35.6 \%$ & & \\
\hline
\end{tabular}

Education

Primary/None

$\begin{array}{rrrrrr}571 & 22.8 \% & 990 & 39.5 \% & 942 & 37.6 \% \\ 619 & 19.0 \% & 1,165 & 35.7 \% & 1,479 & 45.3 \% \\ 300 & 12.5 \% & 960 & 39.9 \% & 1,144 & 47.6 \%\end{array}$

Third/Higher

Marital status

Married

$920 \quad 16.3 \% \quad 2,179$

$45.0 \%$

$110.8<.001^{* *}$ 
Never married

Separated/Divorced

Widowed

MHD indicator variables

\section{(Exposure variables)}

Emotional, nervous or psychiatric

problem (self-reported doctor

diagnosed) Lifetime prevalence

Self-reported psychiatric

medication use(antidepressant,

antipsychotic or anxiolytic) (Self-

reported) Current prevalence

Antidepressant

Antipsychotic

Anxiolytic

Alcohol/substance abuse (self-

reported doctor diagnosed)

Lifetime prevalence

$\begin{array}{lrrrrr}162 & 20.5 \% & 311 & 39.3 \% & 318 & 40.2 \% \\ 186 & 33.8 \% & 186 & 33.8 \% & 179 & 32.5 \% \\ 223 & 18.7 \% & 441 & 36.9 \% & 531 & 44.4 \%\end{array}$

$36.6 \%$

$35.9 \%$

$45.7<.001 * *$

$27.2 \%$

269

$36.6 \%$

266

$36.2 \%$

$46.4<.001^{* *}$

148

$26.4 \%$

206

$36.8 \%$

206

$36.8 \%$

$28.8<.001^{* *}$

$\begin{array}{lll}40 & 36.0 \% & 32\end{array}$

$28.8 \%$

39

$35.1 \%$

$23.9<.001^{* *}$

$49 \quad 28.6 \%$

65

$38.0 \%$

57

$33.3 \%$

14.6

$.001^{*}$

57

$43.5 \%$

50

$38.2 \%$

24

$18.3 \%$

66.2

$<.001^{* *}$ 
Depression (CES-D) $(\mathrm{n}=8,044)$

Current prevalence

None/mild ( 7 or less)

Moderate (8-15)

\section{7}

422

296

Severe (16+)

Anxiety (HADS-A) $(n=6,637)$

\section{Current prevalence}

Normal (7 or less)

Possible (8-10)

Probable (11+)

Any smoking-related disease

(outcomes)

Lifetime prevalence (self-reported

doctor diagnosed)

Respiratory

Smoker-related cancers

CVD

Other covariates

IPAQ (Physical Activity) $(n=8,096)$

\section{Current}

Low

Moderate

High

756

199

648
517

459

500

\section{$15.2 \%$}

$19.0 \%$

$30.2 \%$

1,873

856

$38.7 \%$

$38.5 \%$

2,230

944

$46.1 \%$

$42.5 \%$

$34.9 \% \quad 343 \quad 35.0 \%$

$342 \quad 34.9 \%$

$15.1 \%$

$19.4 \%$

1,978

381

$39.4 \%$

$37.2 \%$

2,286

444

$45.5 \%$

$43.4 \%$

$29.0 \%$

201

$33.9 \%$

220

$37.1 \%$

$17.3 \%$

1,573

$42.0 \%$

1,526

$40.7 \%$

44.0

$<.001^{* *}$

$32.4 \%$

$19.3 \%$

143

43.3\%

$51.1 \%$

$16.5 \%$

69
1,479

42.0\%

80
40
1,463

$24.2 \%$

$29.6 \%$

$41.5 \%$

$\begin{array}{cc}70.0 & <.001^{* *} \\ 12.3 & .002^{*} \\ 40.0 & <.001^{* *}\end{array}$

$\begin{array}{rr}\mathbf{1 9 . 9} \% & \mathbf{9 5 5} \\ \mathbf{1 6 . 5 \%} & 1,087 \\ 18.4 \% & 1,044\end{array}$

$36.8 \%$

$39.0 \%$

$38.4 \%$
1,120
1,241

1,173

$43.2 \%$

$44.5 \%$

$43.2 \%$
$11.5 .022^{*}$ 
Alcohol problem (CAGE score of 2

or more) $(n=6,758)$

Lifetime prevalence

Diabetes (self-reported doctor

diagnosed) Lifetime prevalence

Waist $\mathrm{cm}$ (mean and (SD))

( $n=5,863)$ Current
215

$26.4 \%$

390

210

$25.8 \%$

$142.9<.001 * *$

293

$46.2 \%$

231

20.2

$<.001^{* *}$
93.77

(13.9)

97.79

(14.0)

93.95

$\mathrm{F}=55.9<.001^{* *}$ 


\section{Smoking among individuals with MHD}

As shown in Table 2, MHD was significantly associated with smoking status with relative risk ratios for former and current smoking ranging from 1.26 to 1.99 and 1.84 to 4.31 respectively when adjusting for potential confounders. Never smoker was taken as the base category. The adjusted

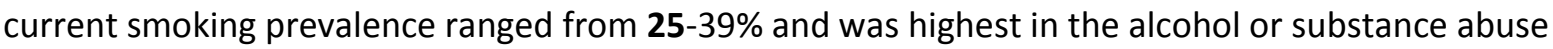
group. This compares to the crude smoking prevalence of $18.24 \%$ in the sample overall. Adjusted former smoking prevalence ranged from $38-41 \%$ which compares to $38 \%$ in the overall sample. The never smoking prevalence was particularly low in the self-reported doctor diagnosed alcohol/substance abuse group (Model 5 ) at $22 \%$, albeit from the initially low absolute prevalence of $1.6 \%$.

Table 2

Adjusted multinomial regression models of smoking status (current/past/never) according to various indicators of MHD for TILDA cohort

\begin{tabular}{|c|c|c|c|c|c|c|c|}
\hline Model & & $n$ & $\begin{array}{l}\text { Adjusted } \\
\text { prevalence }\end{array}$ & $\begin{array}{c}\text { Adjusted } \\
\text { prevalence } \\
\text { for no MHD }\end{array}$ & $\begin{array}{c}\text { Adjusted } \\
\text { RRR }\end{array}$ & $95 \% \mathrm{Cl}$ & $P$ value \\
\hline \multirow[t]{4}{*}{1} & $\begin{array}{l}\text { Emotional, nervous or } \\
\text { psychiatric problem } \\
\text { (self-reported doctor } \\
\text { diagnosed) } \\
\text { Lifetime prevalence }\end{array}$ & 8,154 & & & & & \\
\hline & Never smoker & & $34 \%$ & $44 \%$ & (base) & & \\
\hline & Former smoker & & $39 \%$ & $37 \%$ & 1.33 & $1.10-1.60$ & $.003^{*}$ \\
\hline & Current smoker & & $26 \%$ & $19 \%$ & 1.84 & $1.50-2.26$ & $<.001 * *$ \\
\hline
\end{tabular}

$2 \quad$ Psychiatric medication 8,158

use (Self-reported)

Current prevalence

Never smoker

$35 \%$

$44 \%$

(base)

Former smoker

$38 \%$

$38 \%$

1.26

1.05-1.52

$.012 *$

Current smoker

$27 \%$

$19 \%$

1.84

$1.51-2.25<.001 * *$

Self-reported doctor

diagnosed emotional, nervous or psychiatric problem(Lifetime) and self-reported any psychiatric medication (Current)

Never smoker

$33 \%$

$43 \%$

(base)

Former smoker

$41 \%$

$38 \%$

$1.44 \quad 1.11-1.86$

$.006^{*}$ 
Current smoker

4

Self-reported doctor

diagnosed emotional, nervous or psychiatric problem(Lifetime) or self-reported any psychiatric medication (Current)

Never smoker

Former smoker

Current smoker

5

Alcohol/Substance

abuse (self-reported

doctor

diagnosed)

Lifetime prevalence

Never smoker

Former smoker

Current smoker

6

Alcohol/Substance

abuse or Emotional, nervous or psychiatric

problem (self-reported

doctor

diagnosed)

Lifetime prevalence

Never smoker

Former smoker

Current smoker

7

CES-D

Current prevalence

NONE/MILD

(base)

Never smoker

Former smoker

Current smoker

8,158

8,158

8,158

8,029
$26 \%$

$22 \%$

$38 \%$

$39 \%$

$35 \%$

$38 \%$

$26 \%$

$18 \%$

$44 \%$

(base)

$1.26 \quad 1.08-1.46 \quad .003^{*}$

1.87

$1.58-2.21<.001^{* *}$
43\% (base)

$38 \% \quad 1.99 \quad 1.19-3.33 \quad .009 *$

$19 \%$

4.31
$2.47-7.53<.001^{* *}$
$34 \%$

$38 \%$

$28 \%$

$46 \%$

$38 \%$

$17 \%$

MODERATE 
Never smoker

Former smoker

Current smoker

\section{SEVERE}

Never smoker

Former smoker

Current smoker

8

HADS-A

Current prevalence

NORMAL

Never smoker

Former smoker

Current smoker

POSSIBLE ANXIETY

Never smoker

Former smoker

Current smoker

PROBABLE ANXIETY

Never smoker

Former smoker

Current smoker
$41 \%$

$38 \%$

$21 \%$

$35 \%$

$38 \%$

$26 \%$

6,626

(base)

$45 \%$

(base)

$38 \%$

$17 \%$

$41 \%$

$39 \%$

$21 \%$

$36 \%$

(base)

$38 \%$

$25 \%$ (base)

1.01-1.29

$.036^{*}$

$1.33 \quad 1.15-1.54<.001^{* *}$

(base)

1.37

$1.15-1.63<.001^{* *}$

$2.27 \quad 1.88-2.75<.001^{* *}$

Weighted and adjusted for age, sex, education and marital status.

\section{Smoking-related diseases among individuals with MHD}

MHD was also significantly associated with smoking-related disease with odds ratios ranging from 1.24 to 1.62 (Table 3). The adjusted prevalence of smoking-related disease ranged from 53 to $60 \%$ and was highest in the alcohol or substance abuse group. This compares to a crude prevalence of $46 \%$ in the overall sample. As per Baron and Kenny's four steps for mediation, the independent variable, MHD, therefore predicted the dependent variable smoking-related disease (Table 3, middle columns) fulfilling the first step in Baron and Kenny's approach ${ }^{50}$. As per Table 2, the independent variable, MHD, also predicted smoking status thus fulfilling the second step. Further regression analyses confirmed that smoking status predicted smoking-related disease, with significant associations for former smoking (step 3). Finally in relation to step four, the addition of smoking status to models had virtually no impact indicating that smoking status was not a mediator of the association between MHD and smoking-related disease (Table 3, right columns) ${ }^{50}$. 
Table 3

Adjusted logistic regression models of any smoking-related disease (respiratory disease, cardiovascular disease or smoking-related cancer) according to various indicators of MHD for TILDA cohort and with mediational analysis adjusting for smoking status (never/past/current)

\begin{tabular}{|c|c|c|c|c|c|c|c|c|c|c|}
\hline \multirow[t]{3}{*}{ Model } & & \multirow[b]{3}{*}{$\mathbf{n}$} & \multirow[b]{3}{*}{$\begin{array}{c}\text { Adjusted } \\
\text { prevalence } \\
\text { smoking-related } \\
\text { disease } \\
\end{array}$} & \multirow[b]{3}{*}{$\begin{array}{c}\text { Adjusted } \\
\text { prevalence } \\
\text { smoking-related } \\
\text { disease for no } \\
\text { MHD }\end{array}$} & \multirow[b]{3}{*}{ Adjusted OR } & \multirow[b]{3}{*}{$95 \% \mathrm{Cl}$} & \multirow[b]{3}{*}{$P$ value } & \multicolumn{3}{|c|}{ Mediation analysis } \\
\hline & & & & & & & & Adjusted OR & $95 \% \mathrm{Cl}$ & $P$ value \\
\hline & & & & & & & & & & \\
\hline 1 & $\begin{array}{l}\text { Emotional, nervous or } \\
\text { psychiatric problem (self- } \\
\text { reported doctor } \\
\text { diagnosed) } \\
\text { Lifetime prevalence }\end{array}$ & 5,176 & $53 \%$ & $48 \%$ & 1.24 & $1.01-1.51$ & $.036^{*}$ & 1.23 & $1.01-1.51$ & $.039 *$ \\
\hline 2 & $\begin{array}{l}\text { Psychiatric medication use } \\
\text { (self-reported) } \\
\text { Current prevalence }\end{array}$ & 5,176 & $55 \%$ & $48 \%$ & 1.38 & $1.12-1.70$ & $.002^{*}$ & 1.38 & $1.12-1.70$ & $.002^{*}$ \\
\hline 3 & $\begin{array}{l}\text { Self-reported doctor } \\
\text { diagnosed emotional, } \\
\text { nervous or psychiatric } \\
\text { problem(Lifetime) and self- } \\
\text { reported any psychiatric } \\
\text { medication (Current) }\end{array}$ & 5,176 & $57 \%$ & $48 \%$ & 1.46 & $1.11-1.93$ & $.007^{*}$ & 1.45 & $1.10-1.92$ & $.008^{*}$ \\
\hline 4 & $\begin{array}{l}\text { Self-reported doctor } \\
\text { diagnosed emotional, } \\
\text { nervous or psychiatric } \\
\text { problem(Lifetime) or self- } \\
\text { reported any psychiatric }\end{array}$ & 5,176 & $53 \%$ & $47 \%$ & 1.27 & $1.07-1.50$ & $.006^{*}$ & 1.27 & $1.07-1.50$ & $.006 *$ \\
\hline
\end{tabular}


medication (Current)

5

\begin{tabular}{|c|c|c|c|c|c|c|c|c|c|}
\hline $\begin{array}{l}\text { Alcohol/Substance abuse } \\
\text { (self-reported doctor } \\
\text { diagnosed) } \\
\text { Lifetime prevalence }\end{array}$ & 5,176 & $60 \%$ & $48 \%$ & 1.62 & $1.00-2.62$ & .048 & 1.63 & $1.01-2.61$ & $.044 *$ \\
\hline $\begin{array}{l}\text { Alcohol/Substance abuse or } \\
\text { Emotional, nervous or } \\
\text { psychiatric problem (self- } \\
\text { reported doctor } \\
\text { diagnosed) } \\
\text { Lifetime prevalence }\end{array}$ & 5,176 & $54 \%$ & $48 \%$ & 1.30 & $1.07-1.58$ & $.008^{*}$ & 1.30 & $1.07-1.58$ & $.008^{*}$ \\
\hline $\begin{array}{l}\text { CES-D } \\
\text { Current prevalence }\end{array}$ & 5,114 & & & & & & & & \\
\hline NONE/MILD & & $46 \%$ & & & & & & & \\
\hline MODERATE & & $50 \%$ & & 1.10 & $0.96-1.26$ & .160 & 1.10 & $0.96-1.26$ & .190 \\
\hline SEVERE & & $54 \%$ & & 1.44 & $1.18-1.75$ & $<.001^{* *}$ & 1.43 & $1.18-1.74$ & $<.001^{* *}$ \\
\hline $\begin{array}{l}\text { HADS-A } \\
\text { Current prevalence }\end{array}$ & 5,024 & & & & & & & & \\
\hline NORMAL & & $47 \%$ & & & & & & & \\
\hline POSSIBLE ANXIETY & & $51 \%$ & & 1.10 & $0.93-1.29$ & .261 & 1.10 & $0.93-1.30$ & .256 \\
\hline PROBABLE ANXIETY & & $55 \%$ & & 1.50 & $1.21-1.85$ & $<.001 * *$ & 1.50 & $1.21-1.85$ & $<.001^{* *}$ \\
\hline
\end{tabular}

Weighted and adjusted for age, sex, education, physical activity (IPAQ), waist circumference, alcohol problem (CAGE) and diabetes. 
Table 4

Moderation analysis: Odds ratios for smoking and MHD interaction terms for any smoking-related disease (respiratory disease, cardiovascular disease or smoking-related cancer)

\begin{tabular}{lllll}
\hline Model & $n$ & Adjusted OR & $95 \% \mathrm{Cl}$ & P value
\end{tabular}

$1 \quad$ Emotional, nervous or psychiatric 5,176

problem (self-reported doctor

diagnosed)

Lifetime prevalence

× Past Smoking

0.62

$0.39-0.98$

$.041^{*}$

${ }^{x}$ Current Smoking

0.66

$0.38-1.15$

.142

$2 \quad$ Psychiatric medication use (Self- 5,176

reported) Current prevalence

${ }^{x}$ Past Smoking

1.10

$0.69-1.74$

.699

${ }^{x}$ Current Smoking

Self-reported doctor diagnosed

5,176

emotional, nervous or psychiatric

problem(Lifetime) and self-

reported any psychiatric

medication (Current)

${ }^{x}$ Past Smoking

1.02

$0.53-1.96$

.962

${ }^{x}$ Current Smoking

1.26

0.63-2.55

.513

4

Self-reported doctor diagnosed

5,176

emotional, nervous or psychiatric

problem(Lifetime) or self-reported

any psychiatric medication

(Current)

${ }^{x}$ Past Smoking

0.76

0.52-1.11

.160

${ }^{x}$ Current Smoking

0.77

0.49-1.21

.257

5

Alcohol/Substance abuse (self- $\quad 5,176$

reported doctor

diagnosed)

Lifetime prevalence

${ }^{\times}$Past Smoking

2.08

$0.52-8.34$

.301

${ }^{x}$ Current Smoking

0.83

$0.22-3.08$

.779

6

Alcohol/Substance abuse or

Emotional, nervous or psychiatric

problem (self-reported doctor

diagnosed)

Lifetime prevalence 
${ }^{x}$ Past Smoking

${ }^{x}$ Current Smoking

7

CES-D

Current prevalence

MODERATE

${ }^{x}$ Past Smoking

${ }^{x}$ Current Smoking

SEVERE

${ }^{x}$ Past Smoking

${ }^{x}$ Current Smoking

8

HADS-A

Current prevalence

POSSIBLE ANXIETY

${ }^{x}$ Past Smoking

1.23

$0.85-1.77$

${ }^{x}$ Current Smoking

PROBABLE ANXIETY

${ }^{x}$ Past Smoking

1.05

$0.65-1.70$

0.86

${ }^{x}$ Current Smoking

$1.20 \quad 0.76-1.91$ $\begin{array}{ll}0.47-1.15 & .177 \\ 0.41-1.13 & .139\end{array}$

$\begin{array}{ll}0.47-1.15 & .177 \\ 0.41-1.13 & .139\end{array}$

5,114 $\begin{array}{lll}1.03 & 0.67-1.57 & .899\end{array}$

$1.14 \quad 0.69-1.88 \quad .605$

Weighted and adjusted for age, sex, education, physical activity (IPAQ), waist circumference, alcohol problem (CAGE) and diabetes.

Table 4 presents results from the moderation analysis (see Appendix B for full models). All smoking and MHD interaction terms were non-significant when main effects were included in the model, except one. Past smoking appeared to have a negative moderating effect on the association between self-reported doctor diagnosed emotional, nervous or psychiatric problems and smokingrelated diseases while current smoking had no significant moderating role, although effect sizes were similar. This would suggest that those who self-reported a doctor diagnosed emotional, nervous or psychiatric problem and were former smokers were less likely to have a smoking-related disease, although this result was not replicated in any other model, suggesting it may be spurious.

\section{Discussion}

We reported a number of important findings in a population-based dataset of older people, using multiple indicators of MHD to ensure robustness of findings. MHD, as evidenced by self-reported doctor diagnosed problems, psychiatric medication use and scores on anxiety and depression scales, was associated with smoking status in community living adults aged 50 and over in Ireland. MHD was also associated with the presence of a smoking-related disease i.e. respiratory disease, cardiovascular disease or a smoking-related cancer in this cohort. Contrary to our hypothesis, respondents' smoking status did not mediate the association between MHD and smoking-related disease. While it was expected that higher rates of smoking would be an important factor in the relationship between MHD and smoking-related disease, smoking did not fully explain the increased disease prevalence in this population. The various indicators of MHD revealed similar results. Associations with both current smoking and with smoking-related disease were strongest for self- 
reported doctor diagnosed alcohol/substance use. This was the first study to examine the burden of smoking on the physical health of those with MHD in Ireland at a population level.

The first aim of the current study was to establish the prevalence of smoking and the prevalence of smoking-related disease in older adults with MHD in Ireland. The higher rates of smoking among those with MHD compared to the general population have already been established in the UK, the US and Australia ${ }^{7,9,23}$. Between 2009 and 2011 the general population smoking prevalence among those aged 15 and over in Ireland fell from $24.6 \%$ to $22.9 \%^{52}$. In the current study adjusted current smoking prevalences of 25 to $39 \%$ were found among those with MHD while former smoking prevalences were 38 to $41 \%$. This compares to current smoking prevalences of 25.5 to $59 \%$ among those with $\mathrm{MHD}^{3-9}$ found in previous studies and lifetime prevalences between 55.3 and $81 \%$ with higher rates observed in those with psychosis ${ }^{7,10,11}$.

Increased rates of tobacco-related disease ${ }^{3,28-33}$ have also been shown. The adjusted prevalences of smoking-related disease in the current study ranged from 53 to $60 \%$. Previous studies have found prevalences ranging from 0.9 (peripheral vascular disorder) to 61\% (raised cholesterol) for cardiovascular conditions including cardiac disease and stroke. In relation to respiratory conditions, COPD prevalences of 6.8-45.7\% ${ }^{3,29-32}$ have been reported in previous studies. Cancer morbidity studies reporting prevalence according to MHD appear to be rare though a number of mortality studies have been published.

The second aim of this study was to uncover the impact of smoking on the association between MHD and smoking-related disease. However, although the diseases included were selected by the authors to show the burden of tobacco on the physical health of those with MHD in Ireland, in the current study smoking did not mediate this association. In general, smoking status had no moderating role in the association between MHD and smoking-related diseases either. The only exception was a significant negative moderating effect of past smoking on the association between self-reported doctor diagnosed emotional, nervous or psychiatric problems and smoking-related diseases. However given this was present in just one model and not a pattern seen across exposure variables no strong conclusions can be drawn. Previous studies involving psychiatric populations or those with SMI have found elevated odds of respiratory illness, cardiovascular disease and risk of death from cardiovascular disease which were not fully explained by smoking $4,28,34$. Researchers have suggested antipsychotic medications, diet, exercise ${ }^{4}$ smoking intensity (dose-response relationship), inhaling more deeply (as has been indicated in schizophrenia) ${ }^{53,54}$ and greater secondhand smoke exposure ${ }^{28}$ may form part of the explanation. It should also be noted that in the current study, cardiovascular disease, which is known to have risk factors beyond smoking, accounted for the vast majority of smoking-related disease. High cholesterol was also responsible for a large proportion of this CVD and $66 \%$ of the overall smoking-related disease outcome variable was accounted for by those with high cholesterol alone. However, only minor changes were present in a few models when cholesterol was excluded as an outcome, and the overall pattern of results remained (see Appendix C). Respiratory disease and smoking-related cancers accounted for just $4 \%$ of the smoking-related disease outcome modelled. Other risk factors for cardiovascular disease such as physical activity were assessed in this study but may not have been accurate enough to account for all excess risk. For instance, while the IPAQ is said to have reasonable measurement properties for $18-65$ year olds ${ }^{47}$ its reliability with those aged 65 and over has been questioned ${ }^{55}$. It is also possible that other risk factors that were not assessed may be more important.

Overall, individuals with MHD are known to die younger ${ }^{18-22}$ and tobacco-related deaths specifically also seem to occur at an earlier age than in the general population ${ }^{56}$. Given that the current study involved those aged 50 and over it is likely that a proportion of those with MHD are missing from the dataset as they have already died or were terminally ill and therefore not participating. Support for this is provided by the fact that for most MHD indicators (with the exception of medications) case 
respondents were significantly younger compared to the rest of the sample (data not shown). Only one of the studies cited above in describing excess morbidity and mortality was limited to an older population and it concerned those aged 65 and older and hospitalised for acute myocardial infarction ${ }^{27}$. Another study, linking 1,213 inpatient records to death index data, found cigarette smoking contributed to an increased risk of death in schizophrenia patients particularly in those aged 35-54 years but that in older ages (55-69 years) mortality risk was actually lower for smokers ${ }^{57}$. Similarly, Bandiera et al. found persons with MHD, including substance abuse, experience tobaccorelated deaths at earlier ages than the general population but that after age 70 this pattern is reversed and tobacco-related deaths occur more often in the general population ${ }^{56}$.

Although descriptive data indicated that former smokers had higher estimates of smoking-related disease and only former smoking (and not current) was predictive of smoking-related disease, as stated results from the mediation and moderation analysis show that past smoking did not explain the association between MHD and smoking-related disease. We should note in this older sample $38.1 \%$ were former smokers. Furthermore as stated this is a relatively healthy sample, missing those who have already died or were too unwell to participate.

\section{Strengths and Limitations}

Strengths of the current study include the large nationally representative sample of older adults. The TILDA study with its robust methodology provides a detailed and rich population weighted dataset and the necessary power to adjust for many confounders. This large representative sample means results can be generalised to the population ${ }^{39}$. This study also included multiple measures of MHD from self-reported doctor diagnosed conditions to medication use to standardised scales.

This study was limited in that it is representative only of those aged 50 and over who are living in the community. Datasets which do not include younger people or other sectors of society, such as those not living in the community do not provide a full picture and are therefore likely to underestimate disease prevalence, particularly if those excluded tend to experience higher rate of disease and decreased life expectancy as is the case for those with severe mental illness ${ }^{21}$. Osborn et al. accessed the UK General Practitioners Research Database and achieved a large nationally representative community sample of people with SMI which included those in long-term care. However, as they acknowledged, homeless people may not be well-represented and as such the estimated risk of $\mathrm{CHD}$ death may still be even greater than it appears ${ }^{4}$. This is again especially relevant in the case of MHD given, as noted in the UK, the striking disparity of prevalence of psychiatric disorders in different subsections of the population ${ }^{58}$. In addition to these challenges in gaining representative samples of those with SMI the exclusion of those in residential care is also an issue as while this covers only around $2 \%$ of those aged 50 and over, it represents a greater proportion of those in older age categories and people in residential care tend to have more chronic disease ${ }^{59}$. Future research could look to include surveys of institutions and the homeless in addition to households.

This study also largely relied on self-reported doctor diagnosed conditions and involved an older population introducing issues including under diagnosis of conditions and under-reporting. This older sample in particular may potentially under-report conditions and medications due to memory but also due to stigma and social desirability bias ${ }^{60}$, particularly in the case of questions around mental health within the context of a face-to-face interview. A 2007 national survey in Ireland revealed just over half of respondents agreed with the statement 'If I was experiencing mental health problems, I wouldn't want people knowing about it ${ }^{\prime 61}$. Self-report data in relation to smoking has however been shown to be accurate in most studies ${ }^{62}$. 
In addition to potential underreporting, psychiatric medications such as benzodiazepines can be prescribed for short term conditions such as insomnia or as muscle relaxants for pain and thus would not necessarily indicate MHD. Furthermore the role which psychiatric medications themselves can play in terms of weight gain and metabolic effects is also a factor ${ }^{63}$. Nonetheless the similar pattern of results across models (including those based on self-reported doctor diagnosed MHD and scale scores) provides reassurance that this alone was not responsible for the increased risk of disease in those with indicated MHD after controlling for smoking.

Arguably some models were overfitted due to the inclusion of the CAGE questionnaire (for consistency of models) as a covariate when modelling the presence of smoking-related disease based on self-reported doctor diagnosed alcohol/substance abuse however removal had little impact on results (data not shown).

As with all observational studies we cannot rule out the potential for residual confounding. Finally, the fact that it was not possible to include cancers of the lip, the renal pelvis and acute myeloid leukaemia is a further limitation.

\section{Conclusion}

Among older community living adults in Ireland indicators of MHD was associated with a higher prevalence of current smoking and self-reported doctor diagnosed cardiovascular disease, respiratory diseases and smoking-related cancers. This increased risk of smoking-related disease remained even after adjusting for smoking status.

\section{Funding}

This work was supported by the Health Research Board of Ireland (HRB) through the HRB Structured PhD in Population Health and Health Services Research (SPHeRE) programme (SPHeRE/2013/01).

\section{Declaration of Interests}

The authors declare no conflicts of interest.

\section{Acknowledgments}

The authors would like to thank Dr. Mark Ward (Research Fellow at The Irish Longitudinal Study on Ageing) for his comments on a previous version of this manuscript and Ms Siobhan Scarlett (Research Assistant and Data manager at The Irish Longitudinal Study on Ageing) for her guidance on data cleaning.

\section{References}

1. Hickey P, Evans D. Smoking in Ireland 2014: synopsis of key patterns. Dublin: Health Service Executive. 2015.

2. Smoking statistics. ASH: London: Action on Smoking and Health.; June 2016.

3. Partti $\mathrm{K}$, Vasankari $\mathrm{T}$, Kanervisto $\mathrm{M}$, et al. Lung function and respiratory diseases in people with psychosis: population-based study. 2015.

4. Osborn DP, Levy G, Nazareth I, Petersen I, Islam A, King MB. Relative risk of cardiovascular and cancer mortality in people with severe mental illness from the United Kingdom's General Practice Rsearch Database. Arch Gen Psychiatry. 2007;64(2):242-249.

5. Smith PH, Mazure CM, McKee SA. Smoking and mental illness in the U.S. population. Tob Control. 2014;23(e2):e147-153. 
6. McManus S, Meltzer H, Campion J. Cigarette smoking and mental health in England. Data from the Adult Psychiatric Morbidity Survey National Centre for Social Research. 2010.

7. Lasser K, Boyd JW, Woolhandler S, Himmelstein DU, McCormick D, Bor DH. Smoking and mental illness: A population-based prevalence study. Jama. 2000;284(20):2606-2610.

8. Poirier MF, Canceil O, Bayle F, et al. Prevalence of smoking in psychiatric patients. Prog Neuropsychopharmacol Biol Psychiatry. 2002;26(3):529-537.

9. Lawrence D, Mitrou F, Zubrick SR. Smoking and mental illness: results from population surveys in Australia and the United States. BMC Public Health. 2009;9:285-285.

10. Cooper J, Mancuso SG, Borland R, Slade T, Galletly C, Castle D. Tobacco smoking among people living with a psychotic illness: the second Australian Survey of Psychosis. Aust N Z J Psychiatry. 2012;46(9):851-863.

11. Hartz SM, Pato CN, Medeiros $\mathrm{H}$, et al. Comorbidity of severe psychotic disorders with measures of substance use. JAMA Psychiatry. 2014;71(3):248-254.

12. Bowden JA, Miller CL, Hiller JE. Smoking and mental illness: a population study in South Australia. Australian and New Zealand Journal of Psychiatry. 2011;45(4):325-331.

13. Jackson JG, Diaz FJ, Lopez L, de Leon J. A combined analysis of worldwide studies demonstrates an association between bipolar disorder and tobacco smoking behaviors in adults. Bipolar Disord. 2015;17(6):575-597.

14. Zhang XY, Liang J, Chen da C, et al. Cigarette smoking in male patients with chronic schizophrenia in a Chinese population: prevalence and relationship to clinical phenotypes. PLoS One. 2012;7(2):e30937.

15. Control CfD, Prevention. Vital signs: current cigarette smoking among adults aged $\geq 18$ years with mental illness-United States, 2009-2011. MMWR Morbidity and mortality weekly report. 2013;62(5):81.

16. Ho SY, Alnashri N, Rohde D, Murphy P, Doyle F. Systematic review and meta-analysis of the impact of depression on subsequent smoking cessation in patients with chronic respiratory conditions. Gen Hosp Psychiatry. 2015;37(5):399-407.

17. Doyle F, Rohde D, Rutkowska A, Morgan K, Cousins G, McGee H. Systematic review and meta-analysis of the impact of depression on subsequent smoking cessation in patients with coronary heart disease: 1990 to 2013. Psychosom Med. 2014;76(1):44-57.

18. Odegard O. Mortality in Norwegian mental hospitals 1926-1941. Acta Genet Stat Med. 1951;2(2):141-173.

19. Chesney E, Goodwin GM, Fazel S. Risks of all-cause and suicide mortality in mental disorders: a meta-review. World Psychiatry. 2014;13(2):153-160.

20. Chang CK, Hayes RD, Perera G, et al. Life expectancy at birth for people with serious mental illness and other major disorders from a secondary mental health care case register in London. PLoS One. 2011;6(5):e19590.

21. Colton CW, Manderscheid RW. Congruencies in increased mortality rates, years of potential life lost, and causes of death among public mental health clients in eight states. Prev Chronic Dis. 2006;3(2):A42.

22. Lawrence $D$, Hancock KJ, Kisely $\mathrm{S}$. The gap in life expectancy from preventable physical illness in psychiatric patients in Western Australia: retrospective analysis of population based registers. BMJ. 2013;346:f2539.

23. Royal College of Physicians RCoP. Smoking and mental health. London: RCP. Royal College of Psychiatrists Council Report CR1782013.

24. Harker $\mathrm{K}$, Cheeseman, $\mathrm{H}$. The stolen years: The mental health and smoking action report. April 2016.

25. Callaghan RC, Veldhuizen S, Jeysingh $\mathrm{T}$, et al. Patterns of tobacco-related mortality among individuals diagnosed with schizophrenia, bipolar disorder, or depression. J Psychiatr Res. 2014;48(1):102-110. 
26. Tran E, Rouillon F, Loze JY, et al. Cancer mortality in patients with schizophrenia: an 11-year prospective cohort study. Cancer. 2009;115(15):3555-3562.

27. Druss BG, Bradford WD, Rosenheck RA, Radford MJ, Krumholz HM. Quality of medical care and excess mortality in older patients with mental disorders. Arch Gen Psychiatry. 2001;58(6):565-572.

28. Sokal J, Messias E, Dickerson FB, et al. Comorbidity of medical illnesses among adults with serious mental illness who are receiving community psychiatric services. J Nerv Ment Dis. 2004;192(6):421-427.

29. Carney CP, Jones L, Woolson RF. Medical comorbidity in women and men with schizophrenia: a population-based controlled study. J Gen Intern Med. 2006;21(11):11331137.

30. Batki SL, Meszaros ZS, Strutynski K, et al. Medical comorbidity in patients with schizophrenia and alcohol dependence. Schizophr Res. 2009;107(2-3):139-146.

31. Copeland LA, Mortensen EM, Zeber JE, Pugh MJ, Restrepo MI, Dalack GW. Pulmonary disease among inpatient decedents: Impact of schizophrenia. Prog Neuropsychopharmacol Biol Psychiatry. 2007;31(3):720-726.

32. Himelhoch S, Lehman A, Kreyenbuhl J, Daumit G, Brown C, Dixon L. Prevalence of chronic obstructive pulmonary disease among those with serious mental illness. Prevalence. 2004;161(12).

33. Jones DR, Macias C, Barreira PJ, Fisher WH, Hargreaves WA, Harding CM. Prevalence, severity, and co-occurrence of chronic physical health problems of persons with serious mental illness. Psychiatr Serv. 2004;55(11):1250-1257.

34. Gallagher D, O'Regan C, Savva GM, Cronin H, Lawlor BA, Kenny RA. Depression, anxiety and cardiovascular disease: which symptoms are associated with increased risk in community dwelling older adults? J Affect Disord. 2012;142(1-3):132-138.

35. Masterson E, O'Shea B. Smoking and malignancy in schizophrenia. Br J Psychiatry. 1984;145:429-432.

36. Pal SK, Katheria V, Hurria A. Evaluating the older patient with cancer: understanding frailty and the geriatric assessment. CA Cancer J Clin. 2010;60(2):120-132.

37. Who is at Risk for Heart Disease? - NHLBI, NIH. 2016; https://www.nhlbi.nih.gov/health/health-topics/topics/hdw/atrisk]. Accessed 19th September 2016.

38. Savva G. Methodology. Fifty plus in Ireland. 2011:293-303.

39. Barrett A, Burke H, Cronin H, et al. Fifty plus in Ireland 2011: first results from the Irish Longitudinal Study on Ageing (TILDA). 2011.

40. Kearney PM, Cronin H, O'Regan C, et al. Cohort profile: the Irish longitudinal study on ageing. International journal of epidemiology. 2011;40(4):877-884.

41. Warren GW, Alberg AJ, Kraft AS, Cummings KM. The 2014 Surgeon General's report: "The Health Consequences of Smoking-50 Years of Progress": A paradigm shift in cancer care. Cancer. 2014;120(13):1914-1916.

42. Radloff LS. The CES-D scale a self-report depression scale for research in the general population. Applied psychological measurement. 1977;1(3):385-401.

43. Lewinsohn PM, Seeley JR, Roberts RE, Allen NB. Center for Epidemiologic Studies Depression Scale (CES-D) as a screening instrument for depression among community-residing older adults. Psychol Aging. 1997;12(2):277-287.

44. O'Regan C, Cronin H, Kenny RA. 6 Mental Health And Cognitive Function. Fifty Plus in Ireland 2011. 2011:155.

45. Vahia IV, Meeks TW, Thompson WK, et al. Subthreshold depression and successful aging in older women. Am J Geriatr Psychiatry. 2010;18(3):212-220.

46. Zigmond AS, Snaith RP. The hospital anxiety and depression scale. Acta Psychiatr Scand. 1983;67(6):361-370. 
47. Craig $\mathrm{CL}$, Marshall AL, Sjostrom M, et al. International physical activity questionnaire: 12 country reliability and validity. Med Sci Sports Exerc. 2003;35(8):1381-1395.

48. Kenny RA, Whelan BJ, Cronin $\mathrm{H}$, et al. The design of the Irish longitudinal study on ageing. 2010.

49. Mayfield D, McLeod G, Hall P. The CAGE questionnaire: validation of a new alcoholism screening instrument. Am J Psychiatry. 1974;131(10):1121-1123.

50. Baron RM, Kenny DA. The moderator-mediator variable distinction in social psychological research: Conceptual, strategic, and statistical considerations. Journal of personality and social psychology. 1986;51(6):1173.

51. StataCorp L. Stata 13.0. College Station, Texas: StataCorp LP. 2014.

52. HSE. http://www.hse.ie/eng/about/Who/TobaccoControl/Research/Half-Year-TrackerUpdate-2016.pdf. 2016.

53. Olincy A, Young DA, Freedman R. Increased levels of the nicotine metabolite cotinine in schizophrenic smokers compared to other smokers. Biol Psychiatry. 1997;42(1):1-5.

54. Viegi G, Scognamiglio A, Baldacci S, Pistelli F, Carrozzi L. Epidemiology of chronic obstructive pulmonary disease (COPD). Respiration. 2001;68(1):4-19.

55. Tomioka K, Iwamoto J, Saeki K, Okamoto N. Reliability and validity of the International Physical Activity Questionnaire (IPAQ) in elderly adults: the Fujiwara-kyo Study. J Epidemiol. 2011;21(6):459-465.

56. Bandiera FC, Anteneh B, Le T, Delucchi K, Guydish J. Tobacco-related mortality among persons with mental health and substance abuse problems. PLoS One. 2015;10(3):e0120581.

57. Kelly DL, McMahon RP, Wehring HJ, et al. Cigarette smoking and mortality risk in people with schizophrenia. Schizophr Bull. 2011;37(4):832-838.

58. Farrell $\mathrm{M}$, Howes $\mathrm{S}$, Taylor $\mathrm{C}$, et al. Substance misuse and psychiatric comorbidity: an overview of the OPCS National Psychiatric Morbidity Survey. Addict Behav. 1998;23(6):909918.

59. Normand C, Kamiya Y, Timonen V, Whelan B. 7 Health And Social Care Utilisation. Fifty Plus in Ireland 2011. 2011:203.

60. Van de Mortel TF. Faking it: social desirability response bias in self-report research. Australian Journal of Advanced Nursing, The. 2008;25(4):40.

61. Barry MM, Perry I, Van Lente E, et al. SLÁN 2007: Survey of Lifestyle, Attitudes and Nutrition in Ireland. Mental Health and Social Well-Being. 2009.

62. Patrick DL, Cheadle A, Thompson DC, Diehr P, Koepsell T, Kinne S. The validity of selfreported smoking: a review and meta-analysis. Am J Public Health. 1994;84(7):1086-1093.

63. Newcomer JW. Second-generation (atypical) antipsychotics and metabolic effects: a comprehensive literature review. CNS Drugs. 2005;19 Suppl 1:1-93. 
Appendices 


\section{Variables Key:}

\section{OUTCOMES:}

_IBEHsmoker1= former smoker

_IBEHsmoker2= current smoker

smokcond= smoking-related disease

\section{EXPOSURES:}

anymhprob= Emotional, nervous or psychiatric problem (self-reported doctor diagnosed)

SRpsychmeduse $=$ Psychiatric medication use (self-reported)

SRmed_prob = Self-reported doctor diagnosed emotional, nervous or psychiatric problem and selfreported any psychiatric medication

SRmedORprob = Self-reported doctor diagnosed emotional, nervous or psychiatric problem or selfreported any psychiatric medication

ph301_08 = Alcohol/Substance abuse (self-reported doctor diagnosed)

SUorMHprob = Alcohol/Substance abuse or Emotional, nervous or psychiatric problem (self-reported doctor diagnosed)

_IMHdep3_1 = Mild/Moderate depressive symptoms as per CES-D

_IMHdep3_2 = Severe depressive symptoms as per CES-D

_Ihadsacat_1 = possible anxiety as per HADS-A

_Ihadsacat_2 = probable anxiety as per HADS-A

\section{COVARIATES:}

FRwaist $=$ waistcm

BEHcage2 $=$ Alcohol problem as per CAGE

ph201_05= diabetes (self-reported doctor diagnosed)

_IFRexercis_1 = Moderate engagement in Physical activity

_IFRexercis_2 = High engagement in Physical activity

_ledu3_2 = Secondary education (High School) highest achieved

_ledu3_3 = Third level education (Higher education) achieved 


\section{Appendix A}

\section{Table 3: Full models}

\section{Model 1}

(a)Without smoking

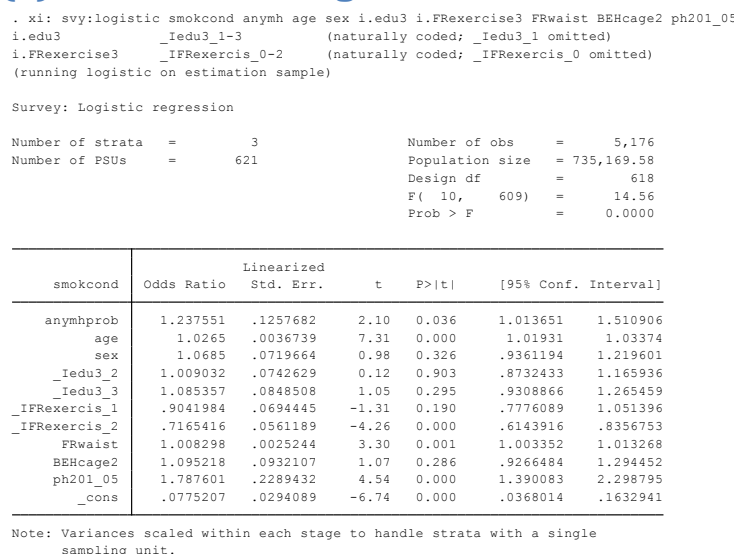

(b) With smoking

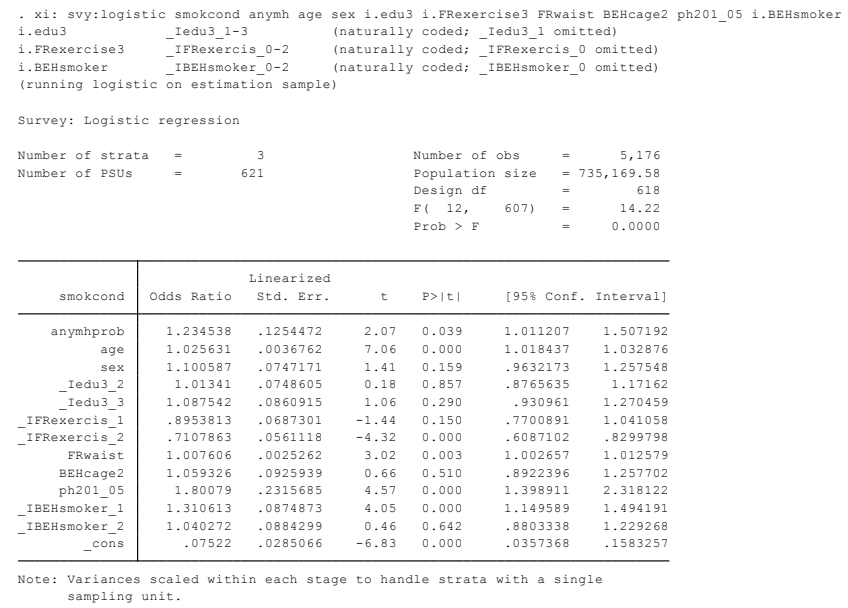

Model 2

(a) Without smoking

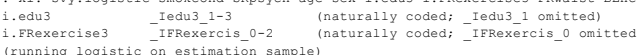

Survey: Logistic regression

$\begin{array}{rlrlrl}\text { Number of strata } & = & 3 & \text { Number of obs } & =5,176 \\ \text { Number of PSUs } & \text { Population size } & =735,169.58 \\ & & \text { Design df } & =618 \\ & \text { F ( 10, 609) } & =14.80 \\ & \text { Prob }>\text { F } & & \end{array}$

\begin{tabular}{|c|c|c|c|c|c|c|}
\hline smokcond & odds Ratio & $\begin{array}{l}\text { Linearized } \\
\text { Std. Err. }\end{array}$ & $t$ & $P>|t|$ & [958 Conf. & Interval] \\
\hline hmeduse & 1.379983 & .1447372 & 3.07 & 0.002 & 1.123108 & 1.695609 \\
\hline & & .0036755 & $7.1 .18=0$ & & & \\
\hline $\operatorname{sex} x$ & $1.059 \mathrm{P}$ & .0713581 & 0.8 & 0.387 & & 20 \\
\hline _Iedu3__2 & $1.017 \mathrm{P} \mathrm{Cl}$ & .0752703 & 0.24 & 0.810 & & 1 \\
\hline ius_-3 & 1.10 & & & & & 13205 \\
\hline _IFRexe & & & -1.16 & & & 1.064 \\
\hline _- IFRexercis_2 & & & -4.12 & & & .8446169 \\
\hline aist & 1.008 & .0025265 & 3.26 & 0.001 & 1.003257 & \\
\hline BEHcage 2 & 1.090501 & .0925329 & 1.02 & 0.308 & .9231174 & 1.288236 \\
\hline $\begin{array}{l}\text { ph201- } 05 \\
\text { pons }\end{array}$ & $\begin{array}{l}1.760399 \\
.0802973\end{array}$ & $\begin{array}{l}.22295266 \\
.0304096\end{array}$ & $\begin{array}{r}4.43 \\
-6.66\end{array}$ & $\begin{array}{l}0.000 \\
0.000\end{array}$ & $\begin{array}{l}1.369705 \\
.0381687\end{array}$ & $\begin{array}{l}2.2625355 \\
.1689252\end{array}$ \\
\hline
\end{tabular}


(b) With smoking

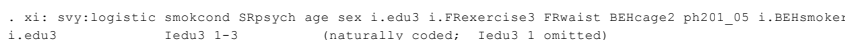

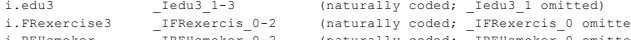

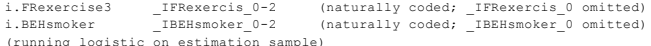

Survey: Logistic regression

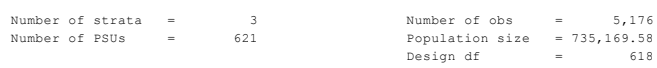

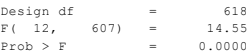

\begin{tabular}{|c|c|c|c|c|c|c|}
\hline smokcond & Odds Ratio & $\begin{array}{l}\text { Linearized } \\
\text { Std. Err. }\end{array}$ & $t$ & $P>|t|$ & [95: Conf. & Interva1] \\
\hline SRpsychmeduse & 1.382203 & .1451107 & 3.08 & 0.002 & 1.12469 & 1.698676 \\
\hline age & & .0036761 & 6.88 & 0.000 & 1.0 & 1.032226 \\
\hline & 1. & & & 0.197 & .9552644 & \\
\hline $\begin{array}{l}-^{\text {Iedulu }^{2}}{ }^{2} \\
\text { Iede }^{3} 3\end{array}$ & 1.021925 & $\begin{array}{l}.0758016 \\
0.074555\end{array}$ & 0.29 & 0.770 & .8833995 & 1.182173 \\
\hline $\begin{array}{l}\text { - Iedu3 }-3 \\
\text { IFexercis }\end{array}$ & $\begin{array}{l}1.100022 \\
.9054861\end{array}$ & $\begin{array}{l}.0874 \\
.0698 \\
\end{array}$ & $\begin{array}{r}1.25 \\
-1.29\end{array}$ & $\begin{array}{l}0.212 \\
0.198\end{array}$ & $\begin{array}{l}.9444696 \\
.7782151\end{array}$ & $\begin{array}{l}1.289845 \\
1.053571\end{array}$ \\
\hline - IFRexercis_- 2 & .71 & & -4.19 & & & $.8=$ \\
\hline & & & & & & \\
\hline BEHcage 2 & 1.055053 & .0919 & 0.61 & 0.539 & .8890592 & 1.25 \\
\hline ph201_05 & 1.773583 & .2275213 & 4.47 & 0.000 & 1.378612 & 2.281712 \\
\hline 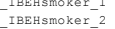 & $\begin{array}{l}1.31 \\
1.03\end{array}$ & $\begin{array}{l}.0875 \\
.0882\end{array}$ & 0.39 & $\begin{array}{l}0.0 \\
0.6\end{array}$ & $\begin{array}{l}1.1449384 \\
.874207\end{array}$ & $\begin{array}{l}1.494286 \\
1.222804\end{array}$ \\
\hline _cons & .0782138 & .0295853 & -6.74 & 0.000 & .0372112 & .1643966 \\
\hline
\end{tabular}

Variances scaled
sampling unit.

\section{Model 3}

(a) Without smoking

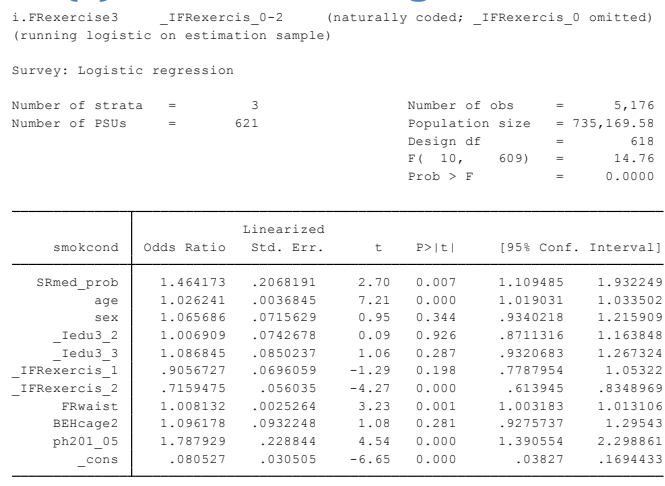

ote: Variances scal
sampling unit.

\section{(b) With smoking}

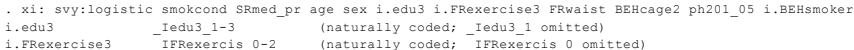

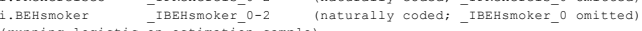

Survey: Logistic regression

$\begin{array}{rlrlrl}\text { Number of strata } & =\quad 3 & & \text { Number of obs } & =5,176 \\ \text { Number of PSUs } & \text { Population size } & =735,169.58 \\ & & \text { Design df } & =618 \\ & \text { F( 12, 607) } & =14.39 \\ & \text { Prob }>\text { F } & & \end{array}$

\begin{tabular}{|c|c|c|c|c|c|c|}
\hline smokcond & odds Ratio & $\begin{array}{l}\text { Linearized } \\
\text { Std. Err. }\end{array}$ & t & $P>|t|$ & [95: Conf. & Interval] \\
\hline SRmed_prob & 1.45431 & .2052323 & 2.65 & 0.008 & 1.1023 & 1.918732 \\
\hline & 1.025382 & .0036856 & 6.97 & 0.000 & 1.018169 & 1.032645 \\
\hline $\operatorname{sex}$ & 1.097712 & . .0743531 & 1.38 & 0.169 & .960991 & 1.253884 \\
\hline _Iedu3_2 & 1.011404 & .0748538 & 0.15 & 0.878 & .8745888 & 1.169622 \\
\hline - Iedu3 ${ }_{3}^{3}$ & 1.089272 & .0862692 & 1.08 & 0.281 & .9323728 & 1.272573 \\
\hline${ }_{-}^{\text {IFRexercis_ }}{ }^{1}$ & .896905 & .0688903 & -1.42 & 0.157 & .7713267 & 1.042929 \\
\hline - IFRexercis_2 2 & .7102466 & .0560302 & -4.34 & 0.000 & .6083135 & .8292603 \\
\hline $\begin{array}{l}\text { FRwaist } \\
\text { BEHcage2 }\end{array}$ & $\begin{array}{l}1.00745 \\
1.06262\end{array}$ & $\begin{array}{l}.0025278 \\
0925926\end{array}$ & $\begin{array}{l}2.96 \\
0.67\end{array}$ & $\begin{array}{l}0.003 \\
0.503\end{array}$ & $\begin{array}{l}1.002498 \\
\end{array}$ & $\begin{array}{r}1.012427 \\
1.25862\end{array}$ \\
\hline $\begin{array}{l}\text { Bencage2 } \\
\text { ph201_05 }\end{array}$ & $\begin{array}{l}1.060262 \\
1.801525\end{array}$ & .09259662 & $\begin{array}{l}0.67 \\
4.58\end{array}$ & $\begin{array}{l}0.503 \\
0.000\end{array}$ & $\begin{array}{r}8931658 \\
1.399568\end{array}$ & $\begin{array}{l}1.25862 \\
2.318924\end{array}$ \\
\hline${ }_{-}$IBEHsmoker ${ }_{-}{ }^{1}$ & 1.309521 & .0873705 & 4.04 & 0.000 & 1.148707 & 1.492848 \\
\hline${ }_{-}$IBEHsmoker-2 2 & 1.041459 & .0884907 & 0.48 & 0.633 & .8814043 & 1.230577 \\
\hline$-^{\text {cons }}$ & .0780183 & .0295173 & -6.74 & 0.000 & .0371127 & .1640101 \\
\hline
\end{tabular}


Model 4

\section{(a) Without smoking}

. $x$ i: svy:logistic smokcond smedoRpro age sex i.edu3 i.FRexercise3 FRwaist BEHcage2 ph201_05

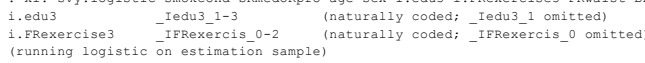

Survey: Logistic regression

$\begin{array}{llll}\text { Number of strata } & =\quad 3 & \text { Number of obs } & =5,176 \\ \text { Number of PSUs } & \text { Population size } & =735,169.58 \\ & \text { Design df } & =18 \\ & \text { F( 10, } 1009) & =14.77 \\ & \text { Prob > F } & =0.0000\end{array}$

\begin{tabular}{|c|c|c|c|c|c|c|}
\hline smokcond & Odds Ratio & $\begin{array}{l}\text { Linearized } \\
\text { Std. Err. }\end{array}$ & $\mathrm{t}$ & $P>|t|$ & (95: Conf. & Interval] \\
\hline SRmedoRprob & 1.266851 & . 108994 & 2.75 & 0.006 & 1.069912 & 1.500039 \\
\hline age & 1.026288 & .0036703 & 7.26 & 0.000 & 1.019105 & 33521 \\
\hline & & & & & 10208 & 1.212236 \\
\hline${ }_{-}^{\text {Iedu3 } 32} 2$ & 1.017199 & .0750028 & 0.23 & 0.817 & .8800748 & 1.175688 \\
\hline $\begin{array}{l}\text { Iedu3 }{ }^{3} \\
\text { xercis } 1\end{array}$ & $\begin{array}{r}1.096644 \\
.9109257\end{array}$ & $\begin{array}{l}.0857825 \\
.0701193\end{array}$ & & 0.239 & $\begin{array}{l}.9404845 \\
.7831073\end{array}$ & 1.278732 \\
\hline $\begin{array}{l}\text { PRexcis }-1 \\
\text { - IFRexercis }\end{array}$ & $\begin{array}{l}.9109257 \\
.722995\end{array}$ & $\begin{array}{l}.0701193 \\
.0567135\end{array}$ & $\begin{array}{l}-1.21 \\
-4.13\end{array}$ & $\begin{array}{l}0.226 \\
0.000\end{array}$ & $\begin{array}{l}.7831273 \\
.6197748\end{array}$ & $\begin{array}{l}1.059579 \\
.8434058\end{array}$ \\
\hline & 1.00 & .0025 & 3.31 & 0.001 & 1.00 & 1.013293 \\
\hline BEHcage 2 & 1.088159 & $\begin{array}{l}.0925 \\
.225 \\
.250\end{array}$ & 0.99 & 0.321 & $\begin{array}{r}.9208344 \\
.373071\end{array}$ & $\begin{array}{l}1.285889 \\
2.269132\end{array}$ \\
\hline cons & $\begin{array}{l}1.765129 \\
.0773209\end{array}$ & $\begin{array}{l}.225762 \\
.0293282\end{array}$ & $\begin{array}{r}4.44 \\
-6.75\end{array}$ & $\begin{array}{l}0.000 \\
0.000\end{array}$ & $\begin{array}{l}1.373071 \\
.0367112\end{array}$ & $\begin{array}{r}2.269132 \\
.1628528\end{array}$ \\
\hline
\end{tabular}

Note: Variances scaled within each stage to handle strata with a single
sampling unit.

\section{(b) With smoking}

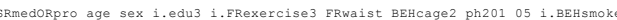

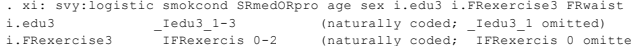
i. BEHsmoker $\quad$ IBEHsmoker_- 0 -2 (naturally coded; ${ }_{-}^{\text {IBEHsmoker_o omitted) }}$ Survey: Logistic regression

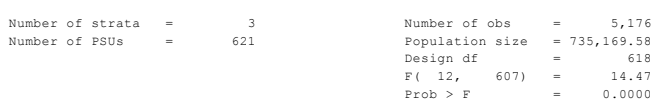

\begin{tabular}{|c|c|c|c|c|c|c|}
\hline smokcond & Odds Ratio & $\begin{array}{l}\text { Linearized } \\
\text { Std. Err. }\end{array}$ & $t$ & $P>|t|$ & [95: Conf. & Interva1] \\
\hline SRmedoRprob & 1.269649 & .1094227 & 2.77 & 0.006 & 1.071964 & 1.503 \\
\hline age & 1. 025382 & .0036724 & 7.00 & 0.000 & 1.018195 & 1.032619 \\
\hline sex & 1.093462 & .0743357 & 1.31 & 0.189 & .9568059 & 1.249636 \\
\hline - Iedu3_ $_{2}$ & 1.021053 & .0755397 & 0.28 & 0.778 & .8829807 & 1.180717 \\
\hline $\begin{array}{l}\text { - Iedu3 } 3 \\
\text { IFrexercis }\end{array}$ & 1.09778 & .0869306 & 1.18 & 0.239 & .9396763 & 1.282484 \\
\hline 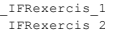 & $\begin{array}{r}.9018409 \\
717092\end{array}$ & .0693701 & $\begin{array}{l}-1.34 \\
-4.21\end{array}$ & 0.180 & .7754013 & $\begin{array}{r}1.048898 \\
8375355\end{array}$ \\
\hline 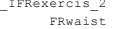 & $\begin{array}{r}.7170925 \\
1.007616\end{array}$ & $\begin{array}{l}.0566933 \\
.0025282\end{array}$ & $\begin{array}{r}-4.21 \\
3.02\end{array}$ & $\begin{array}{l}0.000 \\
0.003\end{array}$ & $\begin{array}{r}.61397 \\
1.02663\end{array}$ & $\begin{array}{r}.8375355 \\
1.012593\end{array}$ \\
\hline $\begin{array}{l}\text { BeHcage2 } \\
\text { BEHcage }\end{array}$ & $\begin{array}{l}1.052865 \\
1.056\end{array}$ & .0919195 & 0.59 & 0.555 & .8869787 & 1.249775 \\
\hline ph201_05 & 1.778148 & .2282504 & 4.48 & 0.000 & 1.381942 & 2.287947 \\
\hline 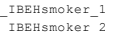 & $\begin{array}{l}1.310445 \\
1.032335\end{array}$ & $\begin{array}{l}.087583 \\
.081112\end{array}$ & 4.05 & 0.000 & $\begin{array}{l}1.149258 \\
873253\end{array}$ & $\begin{array}{l}1.494239 \\
1.220715\end{array}$ \\
\hline 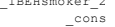 & $\begin{array}{l}.0754188 \\
.07535\end{array}$ & .0285646 & -6.82 & 0.000 & $\begin{array}{l}.8730253 \\
.0358474\end{array}$ & $\begin{array}{l}1.220715 \\
.1586725\end{array}$ \\
\hline
\end{tabular}

\section{Model 5}

(c) Without smoking

\begin{tabular}{|c|c|c|c|c|}
\hline Number of strata & $=$ & 3 & Number of obs & 5,176 \\
\hline Number of PSUs & $=$ & 621 & Population size & $=735,169.58$ \\
\hline & & & F( 10, 609) & $\begin{array}{r}=\quad 14.40 \\
=\quad 0.0000\end{array}$ \\
\hline
\end{tabular}

\begin{tabular}{|c|c|c|c|c|c|c|}
\hline smokcond & Odds Ratio & $\begin{array}{l}\text { Linearized } \\
\text { Std. Err. }\end{array}$ & t & $P>|t|$ & {$[95 \%$ Conf. } & Interval] \\
\hline ph301_08 & 1.621718 & .3960678 & 1.98 & 0.048 & 1.003877 & 2.61981 \\
\hline & 1.026179 & .0036752 & 7.22 & 0.000 & 1.018987 & 1.033422 \\
\hline $\operatorname{sex}$ & 1.088015 & .0735384 & 1.25 & 0.212 & .9527739 & 1.242454 \\
\hline${ }_{-}^{\text {Iedu3 }}{ }^{2}{ }^{2}$ & 1.009965 & .0743475 & 0.13 & 0.893 & .8740232 & 1.16705 \\
\hline - Iedu3 ${ }^{3}{ }^{3}$ & 1.090482 & .0850749 & 1.11 & 0.267 & .9355801 & 1.271031 \\
\hline _IFRexercis_ 1 & .9045659 & .0697545 & -1.30 & 0.194 & .7774493 & 1.052467 \\
\hline _IFRexercis_2 2 & .7136885 & .0560787 & -4.29 & 0.000 & .6116366 & .8327678 \\
\hline FRwaist & 1.008419 & .002524 & 3.35 & 0.001 & 1.003475 & 1.013388 \\
\hline BEHcage 2 & 1.089362 & .0927134 & 1.01 & 0.315 & .9216928 & 1.287534 \\
\hline ph201_05 & 1.791575 & .2293781 & 4.55 & 0.000 & 1.393287 & 2.303719 \\
\hline _cons & .0768554 & .0291881 & -6.76 & 0.000 & .0364562 & .1620234 \\
\hline
\end{tabular}

sampling unit. 


\section{(b) With smoking}

. xi: svy:logistic smokcond ph301_08 age sex i.edu3 i.FRexercise3 FRwaist BEHcage2 i.BEHsmoker ph201_05 i.edu3 $\quad$ Iedu3 $1-3 \quad$ (naturally coded; Iedu3_1 omitted)

$\begin{array}{lll}\text { 1. REHsmoker } & \text { IBEHsmoker_0-2 } & \text { (naturally coded; - IBEHsmoker_o omitted) }\end{array}$

(running logistic on estimation sample)

Survey: Logistic regression

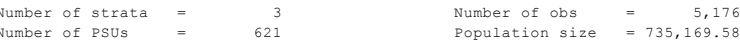

Design df $=\quad 618$

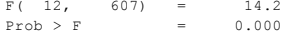

\begin{tabular}{|c|c|c|c|c|c|c|}
\hline smokcond & Odds Ratio & $\begin{array}{l}\text { Linearized } \\
\text { Std. Err. }\end{array}$ & t & $P>|t|$ & [958 Conf. & Interval] \\
\hline ph301_08 & 1.626877 & .3915438 & 2.02 & 0.044 & 1.014127 & 2.60986 \\
\hline age & 1.025301 & .0036757 & 6.97 & 0.000 & 1.018108 & 1.032545 \\
\hline $\operatorname{sex}$ & 1.120745 & .0763921 & 1.67 & 0.095 & .9803328 & 1.281269 \\
\hline _Iedu3_2 & 1.014118 & .0749238 & 0.19 & 0.850 & .877158 & 1.172464 \\
\hline -Iedu3_-3 & 1.09231 & .086246 & 1.12 & 0.264 & .935417 & 1.275518 \\
\hline _IfRexercis_- 1 & .8956376 & .0690385 & -1.43 & 0.153 & .769822 & 1.042016 \\
\hline _IFRexercis_2 2 & .707908 & .0560795 & -4.36 & 0.000 & .6059175 & .827066 \\
\hline FRwaist & 1.00772 & .0025279 & 3.07 & 0.002 & 1.002768 & 1.012697 \\
\hline BEHcage 2 & 1.053633 & .0921944 & 0.60 & 0.551 & .8872828 & 1.251172 \\
\hline _IBEHsmoker__ & 1.311328 & .0878709 & 4.04 & 0.000 & 1.149638 & 1.495758 \\
\hline _LEHSmoker_2 & 1.037771 & .088609 & 0.43 & 0.664 & .8775665 & 1.227222 \\
\hline ph201_05 & 1.804705 & .232084 & 4.59 & 0.000 & 1.401934 & 2.323192 \\
\hline cons & .0746714 & .0283481 & -6.83 & 0.000 & .0354301 & .1573755 \\
\hline
\end{tabular}

Note: Variances scaled within each stage to handle strata with a single sampling unit.

\section{Model 6}

\section{(a) Without smoking}

- xi: svy:logistic smokcond SUorMHprob age sex i.edu3 i.FRexercise3 FRwaist BEHcage2 ph201_05 1.edu3 _Iedu3_1-3 (naturally coded; Iedu3 1 omitted) 1.FRexercise3 IFRexercis_0-2 (naturally coded; _IFRexercis_O omitted) Survey: Logistic regression

$\begin{array}{rlrll}\text { Number of strata } & 3 & & \text { Number of obs } & =5,176 \\ \text { Number of PSUs } & 621 & \text { Population size } & =735,169.58 \\ & & \text { Design df } & =618 \\ & \text { F( 10, 609) } & =14.81 \\ & \text { Prob > F } & =0.0000\end{array}$

\begin{tabular}{|c|c|c|c|c|c|c|}
\hline smokcond & Odds Ratio & $\begin{array}{c}\text { Linearized } \\
\text { Std. Err. }\end{array}$ & t & $P>|t|$ & [95\% Conf. & Interval] \\
\hline SUorMHprob & 1.299556 & .1278101 & 2.66 & 0.008 & 1.071312 & 1.576428 \\
\hline age & 1.026585 & .0036754 & 7.33 & 0.000 & 1.019393 & 1.033829 \\
\hline $\operatorname{sex}$ & 1.070687 & .0720582 & 1.01 & 0.311 & .9381311 & 1.221973 \\
\hline _Iedu3_2 & 1.009466 & .0743245 & 0.13 & 0.898 & .8735683 & 1.166505 \\
\hline _Iedu3 3 & 1.084879 & .0847556 & 1.04 & 0.297 & .9305742 & $1.264^{\circ}$ \\
\hline IFRexercis_1 & .9043058 & .069484 & -1.31 & 0.191 & .7776486 & 1.051592 \\
\hline IFRexercis_2 & .7166433 & .0561191 & -4.25 & 0.000 & .6144919 & .8357762 \\
\hline FRwaist & 1.008295 & .0025262 & 3.30 & 0.001 & 1.003346 & 1.0132 \\
\hline BEHcage2 & 1.084347 & .092782 & 0.95 & 0.344 & .9166266 & 1.282756 \\
\hline ph201_05 & 1.782171 & .2283116 & 4.51 & 0.000 & 1.385763 & 2.291973 \\
\hline _cons & .0764754 & .0290256 & -6.77 & 0.000 & .0362929 & .1611469 \\
\hline
\end{tabular}

Note: Variances scaled within each stage to handle strata with a single sampling unit. 


\section{(b) With smoking}

xi: Svy:logistic smokcond SUorMHprob age sex i.edu3 i.FRexercise3 FRwaist BEHcage2 i.BEHsmoker ph201_05 i.edu3 -Iedu3_1-3 (naturally coded; _Iedu3_1 omitted)

i.FRexercise 3 - IFRexercis_0-2 (naturally coded; _IFRexercis_0 omitted) i.BEHsmoker_ $\quad$ IBEHsmoker_0-2 (naturally coded; _ IBEHsmoker_0 omitted) (running logistic on estimation sample)

Survey: Logistic regression

Number of strata $=3$

Number of PSUs $=621$

$\begin{array}{llr}\text { Number of obs } & =5,176 \\ \text { Population size } & =735,169.58 \\ \text { Design df } & =r \\ \text { F( 12, } 607) & =14.43 \\ \text { Prob }>\text { F } & =0.0000\end{array}$

\begin{tabular}{|c|c|c|c|c|c|c|}
\hline smokcond & Odds Ratio & $\begin{array}{c}\text { Linearized } \\
\text { Std. Err. }\end{array}$ & t & $P>|t|$ & [95\% conf. & Interval] \\
\hline SUorMHprob & 1.29964 & .1273904 & 2.67 & 0.008 & 1.072074 & 1.575511 \\
\hline age & 1.025686 & .0036773 & 7.07 & 0.000 & 1.01849 & 1.032933 \\
\hline $\operatorname{sex}$ & 1.102559 & .0748111 & 1.44 & 0.151 & .9650113 & 1.259711 \\
\hline _Iedu3_2 & 1.013347 & .0748816 & 0.18 & 0.858 & .8764662 & 1.171606 \\
\hline Iedu3_3 & 1.08616 & .0859171 & 1.04 & 0.297 & .9298874 & 1.268696 \\
\hline _IFRexercis_1 & .895241 & .068751 & -1.44 & 0.150 & .7699149 & 1.040968 \\
\hline _IFRexercis_2 2 & .7107426 & .0561063 & -4.33 & 0.000 & .6086763 & .8299241 \\
\hline ERwaist & 1.007591 & .0025271 & 3.02 & 0.003 & 1.002641 & 1.012566 \\
\hline BEHcage 2 & 1.049351 & .0921615 & 0.55 & 0.584 & .8831109 & 1.246884 \\
\hline _IBEHsmoker_ 1 & 1.30967 & .087511 & 4.04 & 0.000 & 1.148613 & 1.49331 \\
\hline _IBEHsmoker_2 & 1.033824 & .08788 & 0.39 & 0.696 & .8748801 & 1.221645 \\
\hline ph201_-05 & 1.795832 & .2310084 & 4.55 & 0.000 & 1.39494 & 2.311934 \\
\hline _cons & .0745693 & .0282587 & -6.85 & 0.000 & .0354288 & .1569508 \\
\hline
\end{tabular}

Note: Variances scaled within each stage to handle strata with a single sampling unit.

\section{Model 7}

(a) Without smoking

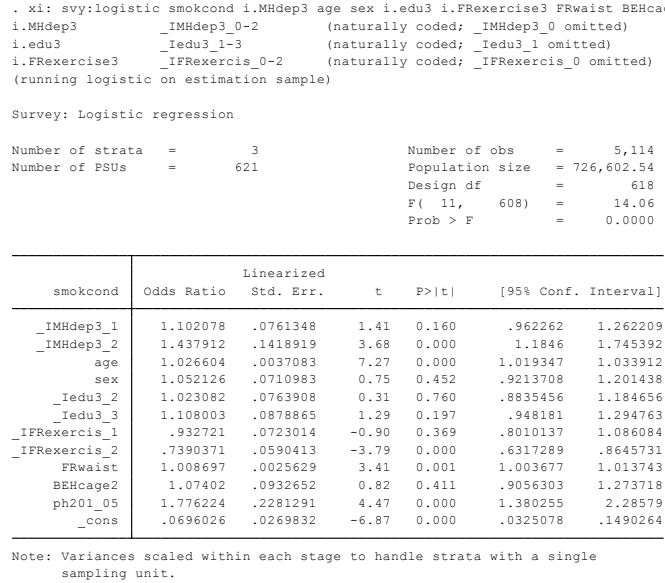

\section{(b)With smoking}

. xi: svy:1ogistie snoend i.MHdep3 age sex i.edu3 i.FRexercise3 FRwaist BEHCage2 ph201 05 i.BEHsmok

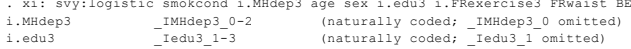

$\begin{array}{lll}\text { i.FRexercise3 } & \text { IFRexercis_0-2 } & \text { (naturally coded; } \\ \text { i.BEHsmoker } & \text { IRRexercis_0 omitted) }\end{array}$

1.BEHsmoker
(running logistic

Survey: Logistic regression

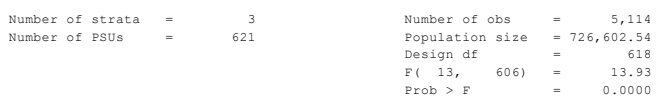

\begin{tabular}{|c|c|c|c|c|c|c|}
\hline smokcond & Odds Ratio & $\begin{array}{l}\text { Linearized } \\
\text { Std. Err. }\end{array}$ & $t$ & $P>|t|$ & [95: Conf. & Inter \\
\hline-1 & 1. & .07 & 1.31 & 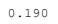 & .955753 & 1.255855 \\
\hline & & & & & & \\
\hline & & & & & & \\
\hline & & & & & & \\
\hline dus & & & 0.34 & & $\begin{array}{r}.8852565 \\
9459786\end{array}$ & 182 \\
\hline Rexerci & & & $\begin{array}{r}1.27 \\
-1.03\end{array}$ & & 年 .998 & 1. \\
\hline 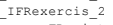 & & & & & & \\
\hline & & & 3.12 & & & \\
\hline & & & 0.45 & & & \\
\hline & $1.7 \mathrm{P}=\mathrm{s}$ & .230 & $\begin{array}{l}4.53 \\
4.22\end{array}$ & & & \\
\hline Hsmoker_z & & .087 & $\begin{array}{l}4.22 \\
0.28\end{array}$ & 0. & $\begin{array}{l}1.1 \\
.865 \\
\end{array}$ & \\
\hline -cons & .0680809 & .026369 & -6.94 & 0.000 & .0318194 & .1456661 \\
\hline
\end{tabular}

Note: Variances scaled
sampling unit. 


\section{Model 8}

\section{(a) Without smoking}

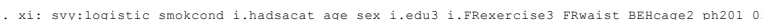

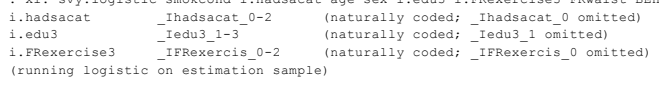

Survey: Logistic regression

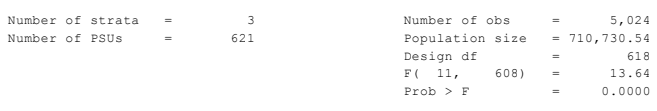

\begin{tabular}{|c|c|c|c|c|c|c|}
\hline smokcond & Odds Ratio & $\begin{array}{l}\text { Linearized } \\
\text { Std. Err. }\end{array}$ & $\mathrm{t}$ & $P>|t|$ & [95음 Conf. & Interval 1$]$ \\
\hline dsacat_1 & 1.09858 & .0917952 & 1.13 & 0.261 & .9323246 & 1.294482 \\
\hline $\mathrm{cat}_{-2}^{2}$ & 1.496827 & .1632717 & 3.70 & 0.000 & 1.208208 & 1.854392 \\
\hline & 1.027706 & .00382 & 7.35 & 0.000 & 1.020231 & 1.035235 \\
\hline $\operatorname{sex}$ & 1.035845 & .0699892 & 0.52 & 0.602 & .9071275 & 1.182826 \\
\hline _Iedu3_2 ${ }^{2}$ & 1.015245 & .076344 & 0.20 & 0.841 & .8758641 & 1.176805 \\
\hline Iedu $3_{-}^{3}$ & 1.116682 & .0892559 & 1.38 & 0.168 & .9544645 & 1.306469 \\
\hline - IFRexercis_p $^{-1}$ & .9101549 & .0710517 & -1.21 & 0.228 & .7807922 & 1.060951 \\
\hline${ }_{-}^{\text {IFRexercis_2 } 2}$ & .7301481 & .0579354 & -3.96 & 0.000 & .6247953 & .8532654 \\
\hline FRwaist & 1.009017 & .0024844 & 3.65 & 0.000 & 1.00415 & 1.0 \\
\hline $\begin{array}{l}\text { BEHcage 2 } \\
\text { Bh201 }\end{array}$ & 1.051524 & .0920491 & 0.57 & 0.566 & $\begin{array}{r}.8854409 \\
.3563\end{array}$ & $\begin{array}{l}1.248758 \\
2.263683\end{array}$ \\
\hline $\begin{array}{l}220105 \\
\text { cons }\end{array}$ & $\begin{array}{l}.1 .750679 \\
.0674473\end{array}$ & $\begin{array}{l}.2281942 \\
.0258426\end{array}$ & $\begin{array}{r}4.31 \\
-7.04\end{array}$ & $\begin{array}{l}0.000 \\
0.000\end{array}$ & $\begin{array}{l}1.33763 \\
.0317822\end{array}$ & $\begin{array}{l}2.263683 \\
.1431347\end{array}$ \\
\hline
\end{tabular}

Variances sca
sampling unit.

\section{(b)With smoking}

age sex i.edu3 i.FRexercise3 FRwaist BEHcage2 ph201 05 i. BEHsmok

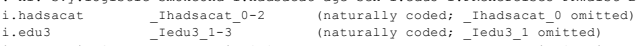
i.FRexercise3 - IFRexercis_0-2 (naturally coded; - IFRexercis_o omitted) (unning logistic on estimation sample) (naturally coded; _ IBEHsmoker_0 omitted

Survey: Logistic regression

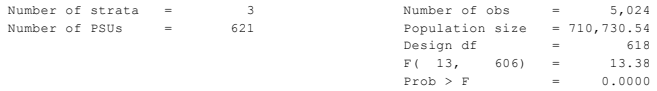

\begin{tabular}{|c|c|c|c|c|c|c|}
\hline smokcond & odds Ratio & $\begin{array}{l}\text { Innearized } \\
\text { std. Err. }\end{array}$ & $t$ & $P>|t|$ & [95: Conf. & I \\
\hline$=1$ & 1.100201 & .0923482 & 1.14 & 0.256 & $.933005 \mathrm{Cl}$ & \\
\hline 列 & & & & & & \\
\hline & 1.026886 & .0038213 & 7.13 & 0.000 & 1.019409 & 118 \\
\hline & 1.064812 & .0726421 & 0.92 & 0.358 & .9312998 & 1.217465 \\
\hline${ }_{-} \mathrm{I}_{\mathrm{S}}$ & & & & & & \\
\hline$-{ }^{I}$ & & & 1.39 & & .9544236 & \\
\hline - IFRexercis_1 & .9006629 & .0702 & -1.34 & 0.181 & .7726849 & 1.049838 \\
\hline 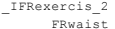 & .723 & $\begin{array}{l}.057 \\
.002\end{array}$ & $\begin{array}{r}-4.04 \\
36\end{array}$ & 0.000 & .6187394 & .8469914 \\
\hline $\begin{array}{l}\text { RRwaist } \\
\text { BEHcage 2 }\end{array}$ & $\begin{array}{l}1.00 \\
1.01\end{array}$ & .0 & $\begin{array}{l}3.36 \\
0.19\end{array}$ & $\begin{array}{l}.001 \\
0.850\end{array}$ & $\begin{array}{l}.003461 \\
.8531103\end{array}$ & $\begin{array}{l}1.1013233 \\
1.212568\end{array}$ \\
\hline & & & 4.34 & & & \\
\hline _ $\mathrm{IBEHSmOK}$ & & & 3.7 & & & 1.483356 \\
\hline${ }_{-}^{\text {IBEHsmoke }}$ & & & 0.4 & & 218 & 29246 \\
\hline _cons & .0657427 & .0250815 & -7.13 & 0.000 & .0310791 & .1390681 \\
\hline
\end{tabular}

Variances scaled within each stage to handle strata witha single

Variances sca
sampling unit. 


\section{Appendix B}

\section{Table 4: Full models}

\section{Model 1}

. svy: Logistic smokcond anymh\#\#BEHsmoker age sex i.edu3 i.FRexercise3 ERwaist BEHcage2 ph201_05

Survey: Logistic regression

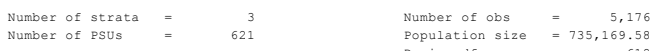

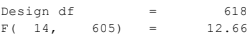

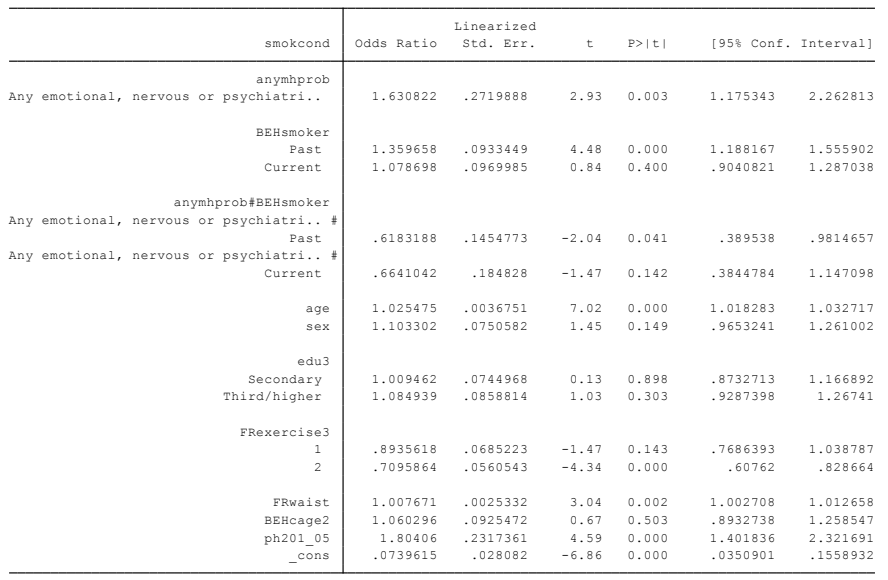

Note: Variances scaled within each stage to handle strata with a single

\section{Model 2}

. svy: logistic smokcond SRpsych\#\#BEHsmok
(running logistic on estimation sampio)

Survey: Logistic regression

$\begin{array}{llr}\text { Number of strata } & = & 3 \\ \text { Number of PSUs } & = & 621\end{array}$

Number of obs $\quad=5,176$

Design df

F 14,605$)=12.48$

\begin{tabular}{|c|c|c|c|c|c|c|}
\hline smokcond & Odds Ratio & $\begin{array}{l}\text { Linearized } \\
\text { Std. Err. }\end{array}$ & t & $p>|t|$ & [95\% conf. & Interval] \\
\hline 1.SRpsychmeduse & 1.297284 & .2088335 & 1.62 & 0.106 & .9456745 & 1.779623 \\
\hline \multicolumn{7}{|l|}{ BEHsmoker } \\
\hline $\begin{array}{r}\text { Past } \\
\text { Current }\end{array}$ & 1.301294 & .0883692 & 3.88 & 0.000 & 1.138827 & 1.486938 \\
\hline & 1.020256 & .0925037 & 0.22 & 0.825 & .8538504 & 1.219093 \\
\hline \\
\hline $\begin{array}{r}\text { 1\#Past } \\
\text { 1\%Current }\end{array}$ & $\begin{array}{l}1.095841 \\
1.136532\end{array}$ & $\begin{array}{r}.2599881 \\
.299006\end{array}$ & $\begin{array}{l}0.39 \\
0.49\end{array}$ & 0.627 & $\begin{array}{l}.688758383 \\
.679581\end{array}$ & $\begin{array}{l}1.744033 \\
1.905288\end{array}$ \\
\hline age & 1.024967 & .0036764 & 6.88 & 0.000 & 1.017773 & 1.032212 \\
\hline sex & 1.091953 & .0741545 & 1.30 & 0.196 & .9556201 & 1.247735 \\
\hline edu3 & & & & & & \\
\hline Secondary & 1.022185 & .0759219 & 0.30 & 0.768 & .8834529 & 1.182704 \\
\hline Third/higher & 1.103937 & .0875675 & 1.25 & 0.213 & .9446958 & 1.290021 \\
\hline \multicolumn{7}{|l|}{ FRexercise3 } \\
\hline $\begin{array}{l}1 \\
2\end{array}$ & $\begin{array}{r}.9050218 \\
.717635\end{array}$ & $\begin{array}{l}.0698351 \\
.0568227\end{array}$ & $\begin{array}{l}-1.29 \\
-4.19\end{array}$ & $\begin{array}{l}0.196 \\
0.000\end{array}$ & $\begin{array}{l}.7777644 \\
.6142892\end{array}$ & $\begin{array}{l}1.053101 \\
.8383675\end{array}$ \\
\hline FRwaist & 1. & .00 & 2.98 & 0.003 & 1.0 & \\
\hline вEнсаge 2 & 1.05 & .0921 & 0.62 & 0.534 & 43 & 1.253201 \\
\hline ph201_05 & 1.772415 & .2271 & 4.46 & 0.000 & 1.37 & 2.279776 \\
\hline _cons & .0785821 & .029747 & -6.72 & 0.000 & .0373656 & .1652628 \\
\hline
\end{tabular}

Variances sca
sampling unit. 


\section{Model 3}

. svy: logistic smokcond SRmed_pr\#\#BEHSmoker age sex i.edu3

Survey: Logistic regression

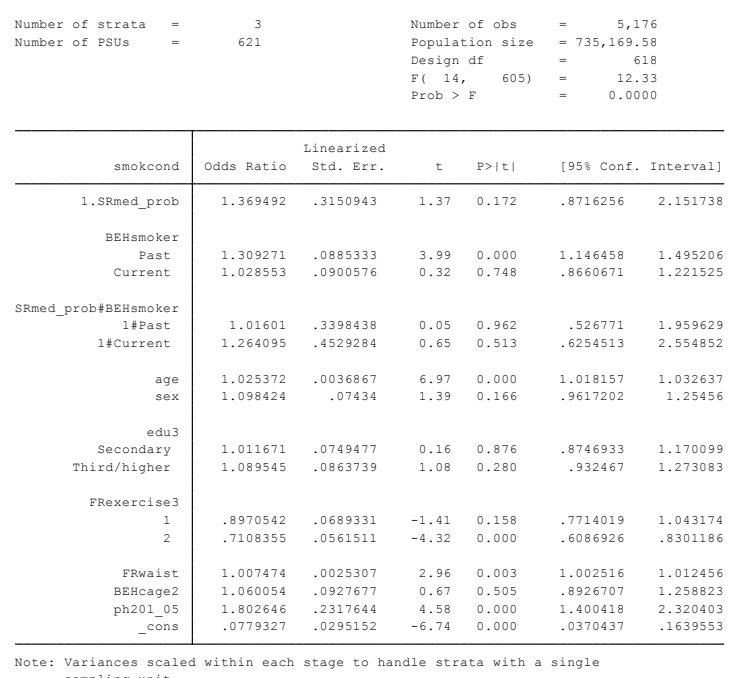

\section{Model 4}

. svy:1ogistic smokcond SRmedoRpro\#\#BEHsmoker age sex i.edu3 i.FRexercise3 FRwaist BEHcage2 ph201_05 (running logistic on estimation sample)

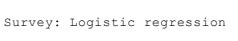

$\begin{array}{llr}\text { Number of strata } & = & 3 \\ \text { Number of PSUs } & = & 621\end{array}$

$\begin{array}{rlr}\text { Number of obs } & =5,176 \\ \text { Population size } & =735,169.58\end{array}$

$\begin{array}{rrr}\text { Design df } & =618 \\ \text { F( 14, } 605) & =12.69\end{array}$

\begin{tabular}{|c|c|c|c|c|c|c|}
\hline smokcond & odds Ratio & $\begin{array}{l}\text { Linearized } \\
\text { Std. Err. }\end{array}$ & t & $p>|t|$ & [95: conf. & Interval] \\
\hline 1. SRmedoRprob & 1.492947 & .2021675 & 2.96 & 0.003 & 1.144334 & 1.947763 \\
\hline BEHsmoker & & & & & & \\
\hline $\begin{array}{l}\text { Past } \\
\text { Current }\end{array}$ & $\begin{array}{l}1.072893 \\
1.0728\end{array}$ & .1005177 & 0.75 & 0.453 & .8925902 & $\begin{array}{l}1.549982 \\
1.289617\end{array}$ \\
\hline SRmedoRprob\# \#EHsmoker & & & & & & \\
\hline $\begin{array}{r}\text { 1\#Past } \\
1 \text { 1\#Current }\end{array}$ & $\begin{array}{r}.759972 \\
.7684323\end{array}$ & $\begin{array}{l}.1481897 \\
.1784267\end{array}$ & $\begin{array}{l}-1.41 \\
-1.13\end{array}$ & $\begin{array}{l}0.160 \\
0.257\end{array}$ & $\begin{array}{l}.5181947 \\
.4870488\end{array}$ & $\begin{array}{r}1.114557 \\
1.21238\end{array}$ \\
\hline age & 1.0 & .0036 & 6.98 & 0.000 & 1.01 & \\
\hline $\operatorname{sex}$ & 1.094029 & .0742 & 1.32 & 0.186 & .95746 & 1.250 \\
\hline edu3 & & & & & & \\
\hline $\begin{array}{r}\text { Secondary } \\
\text { Third/higher }\end{array}$ & $\begin{array}{r}1.01931 \\
1.097228\end{array}$ & $\begin{array}{l}.0754276 \\
.0868643\end{array}$ & $\begin{array}{l}0.26 \\
1.17\end{array}$ & $\begin{array}{l}0.796 \\
0.242\end{array}$ & $\begin{array}{l}.8814442 \\
.9392424\end{array}$ & $\begin{array}{l}1.178739 \\
1.281788\end{array}$ \\
\hline FRexer & & & & & & \\
\hline 1 & .9017 & .0692 & 35 & 0. & .775524 & \\
\hline & & & & & & \\
\hline & & & & & & \\
\hline & 1.77 & $.228 \mathrm{r}-1.0910$ & 4.49 & $\begin{array}{l}0.549 \\
0.000\end{array}$ & $\begin{array}{r}.88829 \\
1.382488\end{array}$ & $\begin{array}{l}1.250424 \\
2.287812\end{array}$ \\
\hline _cons & .0739991 & .0280826 & -6.86 & 0.000 & .0351206 & .1559161 \\
\hline
\end{tabular}

Note: Variances scaled within each stage to handle strata with a single 


\section{Model 5}

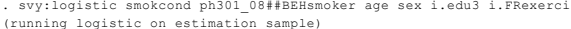

stic regression

Number of strata
Number of PSUs

$\begin{array}{ll}\text { Number of obs } & =5,176 \\ \text { Population size } & =735,169.58\end{array}$

Design $d f$

$\begin{array}{rr}F(14, \quad 605) & =12.16 \\ \text { Prob }>\text { F } & =0.0000\end{array}$

\begin{tabular}{|c|c|c|c|c|c|c|}
\hline smokcond & Odds Ratio & $\begin{array}{l}\text { Linearized } \\
\text { std. Err. }\end{array}$ & $t$ & $P>|t|$ & [95: conf. & Interva1] \\
\hline $\begin{array}{l}\text { ph } 301 \text { _ } 08 \\
\text { Alcohal or substance abuse }\end{array}$ & 1.312154 & .7531831 & 0.47 & 0.636 & .4250424 & 4.05077 \\
\hline $\begin{array}{c}\text { BEHsmoker } \\
\text { Past }\end{array}$ & & & & & & \\
\hline Current & $\begin{array}{l}1.296639 \\
1.052447\end{array}$ & $\begin{array}{l}.08812515 \\
.091518\end{array}$ & 0.59 & $\begin{array}{l}0.0007 \\
0.557\end{array}$ & $\begin{array}{l}.1387117 \\
.8872409\end{array}$ & $\begin{array}{l}1.481803 \\
1.248414\end{array}$ \\
\hline 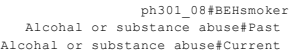 & $\begin{array}{r}2.078484 \\
.829078\end{array}$ & $\begin{array}{l}1.470453 \\
.5544593\end{array}$ & $\begin{array}{c}1.03 \\
-0.28\end{array}$ & $\begin{array}{l}0.301 \\
0.779\end{array}$ & $\begin{array}{l}.5180486 \\
.2229583\end{array}$ & $\begin{array}{l}8.339173 \\
3.082955\end{array}$ \\
\hline age & 1.02 & .003 & 6.99 & 0.000 & 1.0 & 28 \\
\hline & & & & & & \\
\hline $\begin{array}{l}\text { edus } \\
\text { Secondary }\end{array}$ & 1.01 & .074 & & & & \\
\hline Third/higher & 1.091663 & .0862662 & 1.11 & 0.268 & .9347433 & 1.274926 \\
\hline FRexercise3 & & & & & & \\
\hline $\begin{array}{l}1 \\
2\end{array}$ & $\begin{array}{l}.8958383 \\
.7068867\end{array}$ & $\begin{array}{l}.0691116 \\
.0559638\end{array}$ & $\begin{array}{l}-1.43 \\
-4.38\end{array}$ & $\begin{array}{l}0.154 \\
0.000\end{array}$ & $\begin{array}{l}.7698972 \\
.6051018\end{array}$ & $\begin{array}{l}1.042381 \\
.8257929\end{array}$ \\
\hline vaist & 1.007664 & .0025283 & 24 & 0.002 & & \\
\hline & & & 0.67 & 0.505 & & \\
\hline ph201_05 & $1.80 \mathrm{C}>\mathrm{l}$ & .231 & 4.57 & 0.000 & 1.39918 & 2.319508 \\
\hline cons & .0748855 & .0284376 & -6.83 & 0.000 & .035524 & .1578607 \\
\hline
\end{tabular}

Note: Variances scaled
sampling unit.

\section{Model 6}

. svy: 1 ogistic smokcond SUorMHprob\#\#BEHsmoker age sex i.edu3 i.FRexercise3 FRwaist BEHcage2 ph201_05 survey: Logistic regression

\begin{tabular}{|c|c|c|c|c|c|c|}
\hline $\begin{array}{ll}\text { Number of strata } & = \\
\text { Number of PSUs } & =\end{array}$ & $\begin{array}{r}3 \\
621\end{array}$ & & $\begin{array}{l}\text { Number } \\
\text { Popula } \\
\text { Design } \\
\text { F ( } 14 \\
\text { Prob > }\end{array}$ & $\begin{array}{ll}\text { of } & \text { obs } \\
\text { ino } & \text { size } \\
\text { df } & 605) \\
\text { F } & 605\end{array}$ & $\begin{array}{l}=5, \\
=735,169 \\
= \\
=\quad 12 \\
=\quad 0.0\end{array}$ & \\
\hline smokcond & odds Ratio & $\begin{array}{l}\text { Linearized } \\
\text { Std. Err. }\end{array}$ & t & $P>|t|$ & [958 Conf & Interval] \\
\hline 1. suorMAprob & 1.602668 & .2608603 & 2.90 & 0.004 & 1.164192 & 2.206289 \\
\hline $\begin{array}{c}\text { BEHsmoker } \\
\text { Past }\end{array}$ & 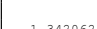 & 00924768 & & & 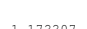 & 57 \\
\hline Current & $\begin{array}{l}1.07202 \\
1.077734\end{array}$ & .0984324 & 0.82 & 0.413 & .9007751 & $\begin{array}{r}1.5653 \\
1.289456\end{array}$ \\
\hline SUorMHprob\#BEH smoker & & & & & & \\
\hline $\begin{array}{r}1 \neq \text { Past } \\
1 \# \text { Current }\end{array}$ & $\begin{array}{l}.7375661 \\
.6824651\end{array}$ & $\begin{array}{l}.1659904 \\
.1758956\end{array}$ & $\begin{array}{l}-1.35 \\
-1.48\end{array}$ & $\begin{array}{l}0.177 \\
0.139\end{array}$ & $\begin{array}{l}.4740901 \\
.4114006\end{array}$ & $\begin{array}{l}1.147469 \\
1.132129\end{array}$ \\
\hline age & 1.025623 & .0036808 & 7.05 & 0.000 & 1.01842 & 1.032877 \\
\hline $\operatorname{sex}$ & 1.101907 & .0747553 & 1.43 & 0.153 & .9644609 & 1.258941 \\
\hline edus & & & & & & \\
\hline $\begin{array}{r}\text { Secondary } \\
\text { Third/higher }\end{array}$ & $\begin{array}{l}1.010323 \\
1.083708\end{array}$ & $\begin{array}{l}.0746615 \\
.0857933\end{array}$ & $\begin{array}{l}0.14 \\
1.02\end{array}$ & $\begin{array}{l}0.890 \\
0.310\end{array}$ & $\begin{array}{l}.8738446 \\
.927698\end{array}$ & $\begin{array}{l}1.168117 \\
1.265992\end{array}$ \\
\hline FRexercise3 & & & & & & \\
\hline $\begin{array}{l}1 \\
2\end{array}$ & .8945133 & .0686612 & -1.45 & 0.147 & .7693464 & 1.040044 \\
\hline & .7095178 & .0560336 & -4.35 & 0.000 & .6075868 & .828549 \\
\hline ERwaist & 1.007603 & .0025321 & 3.01 & 0.003 & 1.002643 & $1.01258 \mathrm{~B}$ \\
\hline BEHcage 2 & 1.05 & .092 & 0.57 & 0.569 & .8847751 & 1.249386 \\
\hline $\begin{array}{l}\text { ph201_o5 } \\
\text { cons }\end{array}$ & $\begin{array}{l}1.799012 \\
.0738442\end{array}$ & $\begin{array}{r}.2312319 \\
.0280062\end{array}$ & $\begin{array}{r}4.57 \\
-6.87\end{array}$ & $\begin{array}{l}0.000 \\
0.000\end{array}$ & $\begin{array}{l}1.397694 \\
0.350935\end{array}$ & $\begin{array}{l}2.31556 \\
1.55566\end{array}$ \\
\hline & & & & & & \\
\hline
\end{tabular}

Variances scated
sampling unit. 


\section{Model 7}

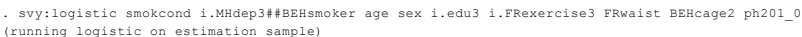
Survey: Logistic regression

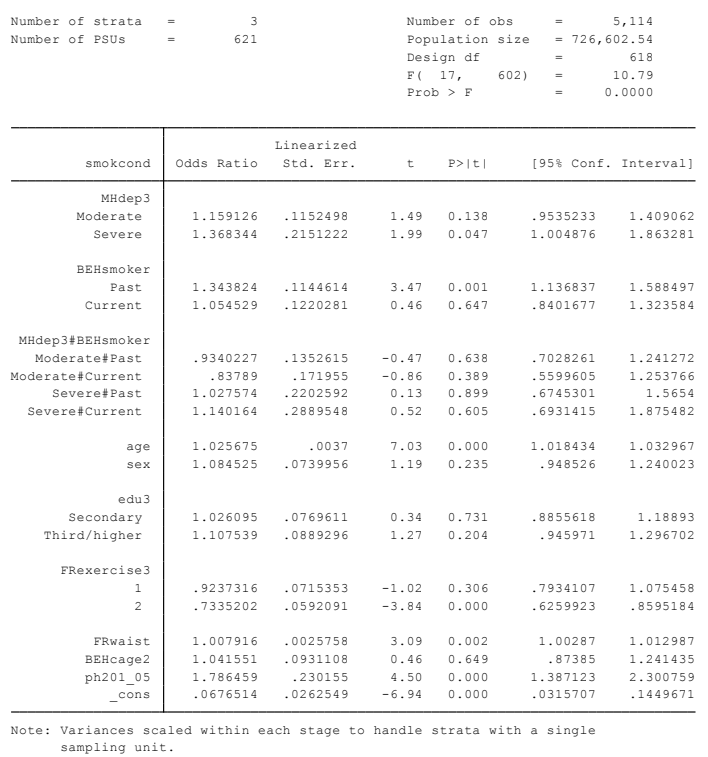

\section{Model 8}

- svy:logistic smok

Survey: Logistic regression

\begin{tabular}{|c|c|c|c|c|c|c|}
\hline $\begin{array}{l}\text { Number of strata } \\
\text { Number of PSUs }\end{array}$ & $\begin{array}{r}3 \\
621\end{array}$ & & & $\begin{array}{l}r \text { of obs } \\
\text { ation size } \\
\text { n df } \\
7, \quad 602) \\
\text { ? }\end{array}$ & $\begin{array}{l}=5, \\
=710,730 \\
=\quad 10 \\
=\quad 0.0 \\
=\quad 0\end{array}$ & $\begin{array}{l}024 \\
.54 \\
618 \\
.40 \\
000\end{array}$ \\
\hline smokcond & odds Ratio & $\begin{array}{l}\text { Linearized } \\
\text { Std. Err. }\end{array}$ & t & $P>|t|$ & [95: Conf. & Interval] \\
\hline $\begin{array}{l}\text { hadsacat } \\
\text { Possible } \\
\text { Probable }\end{array}$ & $\begin{array}{r}.9845129 \\
1.528822\end{array}$ & $\begin{array}{l}.1232845 \\
.2663601\end{array}$ & $\begin{array}{r}-0.12 \\
2.44\end{array}$ & $\begin{array}{l}0.901 \\
0.015\end{array}$ & $\begin{array}{r}.7698773 \\
1.085837\end{array}$ & $\begin{array}{l}1.258987 \\
2.152529\end{array}$ \\
\hline $\begin{array}{c}\text { BEHsmoker } \\
\text { Past } \\
\text { Current }\end{array}$ & $\begin{array}{l}1.249145 \\
1.028897\end{array}$ & $\begin{array}{l}.1002776 \\
.1079946\end{array}$ & $\begin{array}{l}2.77 \\
0.27\end{array}$ & $\begin{array}{l}0.006 \\
0.786\end{array}$ & $\begin{array}{r}1.066957 \\
.837246\end{array}$ & $\begin{array}{l}1.462443 \\
1.264418\end{array}$ \\
\hline $\begin{array}{c}\text { hadsacat\#BEHsmoker } \\
\text { Possible\#past } \\
\text { Possibleflcurrent } \\
\text { Probable\# Past } \\
\text { Probable\#Current }\end{array}$ & $\begin{array}{l}1.228629 \\
1.201007 \\
1.052647 \\
.8614548\end{array}$ & $\begin{array}{l}.2293027 \\
.2829365 \\
.2577016 \\
.2369222\end{array}$ & $\begin{array}{r}1.10 \\
0.78 \\
0.21 \\
-0.54\end{array}$ & $\begin{array}{l}0.270 \\
0.437 \\
0.834 \\
0.588\end{array}$ & $\begin{array}{r}.8516216 \\
.7561771 \\
.650815 \\
.501962\end{array}$ & $\begin{array}{l}1.772535 \\
1.907512 \\
1.702459 \\
1.478408\end{array}$ \\
\hline $\begin{array}{l}\text { age } \\
\text { sex }\end{array}$ & $\begin{array}{l}1.026921 \\
1.064691\end{array}$ & $\begin{array}{l}.0038267 \\
.0727707\end{array}$ & $\begin{array}{l}7.13 \\
0.92\end{array}$ & $\begin{array}{l}0.000 \\
0.359\end{array}$ & $\begin{array}{l}1.019434 \\
.9309591\end{array}$ & $\begin{array}{l}1.034464 \\
1.217634\end{array}$ \\
\hline $\begin{array}{c}\text { edu3 } \\
\text { Secondary } \\
\text { Third/higher }\end{array}$ & $\begin{array}{l}1.020503 \\
1.121494\end{array}$ & $\begin{array}{l}.0767904 \\
.0903907\end{array}$ & $\begin{array}{l}0.27 \\
1.42\end{array}$ & $\begin{array}{l}0.787 \\
0.155\end{array}$ & $\begin{array}{l}.8803147 \\
.9573197\end{array}$ & $\begin{array}{l}1.183017 \\
1.313824\end{array}$ \\
\hline $\begin{array}{c}\text { FRexercise } 3 \\
1 \\
2\end{array}$ & $\begin{array}{r}.901794 \\
.7245489\end{array}$ & $\begin{array}{l}.070335 \\
.0578781\end{array}$ & $\begin{array}{l}-1.33 \\
-4.03\end{array}$ & $\begin{array}{l}0.186 \\
0.000\end{array}$ & $\begin{array}{l}.7737274 \\
.6193539\end{array}$ & $\begin{array}{l}1.051058 \\
.8476108\end{array}$ \\
\hline $\begin{array}{r}\text { ERwaist } \\
\text { BEHcage2 } \\
\text { ph201_05 } \\
\text { cons }\end{array}$ & $\begin{array}{l}1.008291 \\
1.013822 \\
1.773076 \\
.0667862\end{array}$ & $\begin{array}{l}.0024944 \\
.0908063 \\
.2318277 \\
.025566\end{array}$ & $\begin{array}{r}3.34 \\
0.15 \\
4.38 \\
-7.07\end{array}$ & $\begin{array}{l}0.001 \\
0.878 \\
0.000 \\
0.000\end{array}$ & $\begin{array}{l}1.003404 \\
.8502882 \\
1.371561 \\
.0314923\end{array}$ & $\begin{array}{l}1.013201 \\
1.208793 \\
2.292131 \\
.1416344\end{array}$ \\
\hline
\end{tabular}

lote: Variances scaled within each stage to handle strata with a single
sampling unit. 


\section{Appendix C}

\section{Models for smoking-related disease without High Cholesterol}

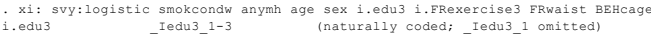

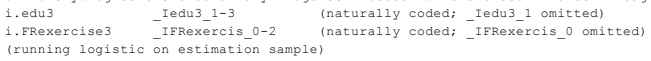

survey: Logistic regression

\begin{tabular}{|c|c|c|c|c|c|c|}
\hline $\begin{array}{l}\text { Number of } \mathrm{stra} \\
\text { Number of } \mathrm{PSUS}\end{array}$ & $=$ & 621 & & 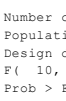 & $\begin{array}{l}\text { obs } \\
\text { size } \\
6009\end{array}$ & $\begin{array}{r}5,176 \\
35,169.58 \\
618 \\
28.15 \\
0.0000\end{array}$ \\
\hline smokcondw & odds Ratio & $\begin{array}{l}\text { Linearized } \\
\text { Std. Err. }\end{array}$ & t & $p>|t|$ & [958: cont & 望 \\
\hline anymprob & 1.22178 & . 1871988 & 1.31 & 0.192 & .9043103 & \\
\hline & $\begin{array}{l}1.059988 \\
.6012562\end{array}$ & $\begin{array}{l}.0054799 \\
.057639\end{array}$ & $\begin{array}{l}11.17 \\
-5.31\end{array}$ & $\begin{array}{l}0.000 \\
0.0000\end{array}$ & $\begin{array}{l}1.048873 \\
.9489921\end{array}$ & \\
\hline 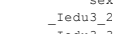 & . & 年. 0775376 & $\begin{array}{l}-2.64 \\
-2.64 \\
-10\end{array}$ & $\begin{array}{l}0.009 \\
0.009\end{array}$ & $\begin{array}{l}.46095318 \\
.627508\end{array}$ & 0 \\
\hline 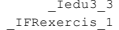 & $\begin{array}{l}.636361777 \\
.9344513\end{array}$ & $\begin{array}{l}.07343774 \\
.0994963\end{array}$ & $\begin{array}{l}-3.92 \\
-0.67 \\
\end{array}$ & $\begin{array}{l}0.000 \\
0.055\end{array}$ & $\begin{array}{l}.5072757 \\
.7654836 \\
\end{array}$ & 57 \\
\hline${ }_{-}^{\text {IFRexercis-2 }}$ & . 5698032 & . 0627627 & -5.11 & 0.000 & .4589684 & \\
\hline $\begin{array}{l}\text { REvalst } \\
\text { BEHсage } 2\end{array}$ & . 1.00587755 & $\begin{array}{l}.1309752 \\
. .06357\end{array}$ & $\begin{array}{r}2.34 \\
-0.68\end{array}$ & $\begin{array}{l}\begin{array}{l}0.019 \\
0.494\end{array} \\
0.94\end{array}$ & $\begin{array}{l}1.001403 \\
.6819567\end{array}$ & \\
\hline $\begin{array}{l}\text { ph201_05 } \\
\text { cons }\end{array}$ & $\begin{array}{l}1.37402 \\
0.055841\end{array}$ & $\begin{array}{l}.2099374 \\
.0033247\end{array}$ & $\begin{array}{r}2.08 \\
-8.71 \\
\end{array}$ & $\begin{array}{l}0.038 \\
0.000\end{array}$ & $\begin{array}{l}1.017847 \\
.0017344\end{array}$ & 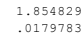 \\
\hline
\end{tabular}

Note: Variances scaled
sampling unit.

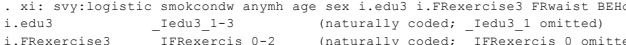

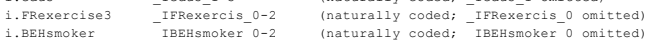
(running logistic on estimation sample)

Survey: Logistic regression

$\begin{array}{lll}\text { Number of strata } & = & \\ \text { Number of PSUs } & = & 621\end{array}$

Number of obs

$\begin{array}{llr}\text { Design df } & =618 \\ \text { F( 12, } 607) & =26.83\end{array}$

\begin{tabular}{|c|c|c|c|c|c|c|}
\hline smokcondw & odds Ratio & $\begin{array}{l}\text { Linearized } \\
\text { Std. Err. }\end{array}$ & t & $P>|t|$ & [95: Conf. & Interval] \\
\hline hprob & 1.176805 & .1789214 & 1.07 & 0.285 & .8730398 & 1.58 \\
\hline & & .0054983 & 11.34 & 0.000 & & 82 \\
\hline & .6564685 & .0639991 & -4.32 & 0.000 & & 4 \\
\hline - Iedu3 $^{2}{ }^{2}$ & .7906697 & .0806304 & -2.30 & 0.022 & & .9 \\
\hline${ }_{-}^{\text {Iedu3 } 3}{ }^{3}$ & .6622479 & .0773 & -3.53 & 0.000 & & 8329704 \\
\hline - IFRexercis_1 1 & .9384052 & .0952 & -0.63 & 0.531 & .768 & 1.145455 \\
\hline $\begin{array}{r}\text { IFRexercis_z } \\
\text { FRavaiss }\end{array}$ & .5730 & .0631 & & 0.000 & & .7116316 \\
\hline $\begin{array}{r}\text { FRwaist } \\
\text { BEHage } 2\end{array}$ & $\begin{array}{l}1.008371 \\
\end{array}$ & .0037073 & 2.27 & 0.024 & $\begin{array}{l}1.0011177 \\
\end{array}$ & $\begin{array}{l}1.015678 \\
1.88739\end{array}$ \\
\hline $\begin{array}{l}\text { BEAcage2 } \\
\text { ph201_05 }\end{array}$ & $\begin{array}{r}8.8166668 \\
1.356291\end{array}$ & $\begin{array}{l}.1190619 \\
.2108596\end{array}$ & $\begin{array}{r}-1.39 \\
1.96\end{array}$ & $\begin{array}{l}0.165 \\
0.050\end{array}$ & $\begin{array}{l}.6133447 \\
.9994446\end{array}$ & $\begin{array}{r}1.08739 \\
1.840547\end{array}$ \\
\hline${ }_{-}^{\text {IBEHsmoker_ }}{ }^{1}$ & 1.758 & .16 & 6.16 & & $1.4 \mathrm{e}$ & 2.105711 \\
\hline noker-2 & & .230 & 4.37 & 0.000 & & 2.2 \\
\hline _cons & .0033439 & .002013 & -9.47 & 0.000 & .0010253 & .0109059 \\
\hline
\end{tabular}

1. svy:logistic smokcondw SRpsych age sex i.edu3 i.fRexercise3 FRwaist BEHcage2 ph201_05

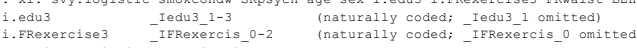

(running logistic on estimation sample)

Survey: Logistic regressio

$\begin{array}{rlrlrl}\text { Number of strata } & = & 3 & \text { Number of obs } & =5,176 \\ \text { Number of PSUs } & \text { Population size } & =735,169.58 \\ & & \text { Design df } & =618 \\ & \text { F( 10, 609) } & =28.36 \\ & \text { Prob }>\text { F } & \end{array}$

\begin{tabular}{|c|c|c|c|c|c|c|}
\hline smokcondw & Odds Ratio & $\begin{array}{l}\text { Linearized } \\
\text { Std. Err. }\end{array}$ & $\mathrm{t}$ & $P>|t|$ & [95음 Conf. & Interval] \\
\hline SRpsychmeduse & 1 . & 77889 & 3.17 & 0.002 & 1.171288 & \\
\hline & 1.058919 & 5 & 11.11 & 0.000 & & 069686 \\
\hline & .59009 & .0569132 & -5.47 & 0.000 & .4882702 & 24 \\
\hline Hu3_-2 & .7776889 & .0796243 & -2.46 & 0.014 & .6360393 & \\
\hline : $143=3$ & $.651 \mathrm{~S}$ & . & & 0. & 1 & \\
\hline _IFRexe & .949 & . 0969 & -0.50 & 0. & 12 & 1.160 \\
\hline${ }_{\text {-IFRexercis_- }}{ }^{2}$ & .5802 & .0638 & -4.95 & 0.000 & .4675553 & .7201557 \\
\hline & 1.008472 & .003 & 2.28 & 0.023 & 1.001165 & 1.015832 \\
\hline BEHcage 2 & .8935293 & .1291474 & -0.78 & 0.436 & .6727255 & 1.186806 \\
\hline ph201_ 05 & $\begin{array}{l}1.343197 \\
.0057971\end{array}$ & $\begin{array}{l}.2043657 \\
.003461\end{array}$ & $\begin{array}{r}1.93 \\
-8.63\end{array}$ & $\begin{array}{l}0.054 \\
0.000\end{array}$ & $\begin{array}{l}.9950867 \\
.0017948\end{array}$ & $\begin{array}{l}1.8099776 \\
.0187238\end{array}$ \\
\hline
\end{tabular}

variances scaled
sampling unit. 
- xi: svy: 1 ogistic smokcondw ph301_08 age sex i.edu3 i.FRexercise3 FRwaist BEHcage2 ph201_05
i.edu3

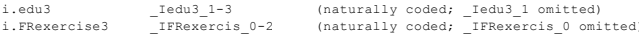

(running logistic on estimation sample)

Survey: Logistic regression

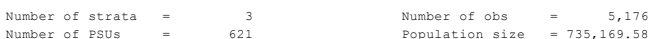

$\begin{aligned} \text { Design df } & =618 \\ \text { E( 10, } 609) & =29.25\end{aligned}$

\begin{tabular}{|c|c|c|c|c|c|c|}
\hline smokcondw & Odds Ratio & $\begin{array}{l}\text { Linearized } \\
\text { Std. Err. }\end{array}$ & $\mathrm{t}$ & $P>|t|$ & [95: conf. & Interval] \\
\hline ph301 08 & 2.233721 & .6120081 & $2.93 \mathrm{Y}>\mathrm{C}$ & 0.003 & 1.304229 & 3.825637 \\
\hline age & 1.059315 & .0054559 & 11.19 & 0.000 & 1.048655 & 1.070084 \\
\hline sex & .6165045 & .0596289 & -5.00 & 0.000 & .5098538 & .7454642 \\
\hline $\begin{array}{l}\text { - Iedu3 }{ }^{2} \\
\text { Iedu3 } 3\end{array}$ & .7686454 & $\begin{array}{l}.077992 \\
.079961\end{array}$ & $\begin{array}{l}-2.59 \\
-3.85\end{array}$ & $\begin{array}{l}0.010 \\
0.000\end{array}$ & $\begin{array}{l}.6297785 \\
5123237\end{array}$ & .9381325 \\
\hline IFRexercis 1 & $\begin{array}{r}.0412493 \\
.934036\end{array}$ & .0951677 & $\begin{array}{l}-3.09 \\
-0.67\end{array}$ & 0.503 & .7646552 & $\begin{array}{l}8043459 \\
1.140937\end{array}$ \\
\hline FRexercis_2 2 & .5671 & .0624435 & -5.15 & 0.000 & .4568349 & .7040048 \\
\hline FRwaist & 1.008804 & .0037295 & 2.37 & 0.018 & 1.001507 & 1.016155 \\
\hline $\begin{array}{l}\text { BEHcage } 2 \\
\text { phro1 } 05\end{array}$ & $\begin{array}{r}.8717492 \\
1.378422\end{array}$ & .1282 & $\begin{array}{r}-0.93 \\
2.10\end{array}$ & $\begin{array}{l}0.351 \\
0.036\end{array}$ & $\begin{array}{r}6530258 \\
1.021306\end{array}$ & $\begin{array}{l}1.163731 \\
1.860408\end{array}$ \\
\hline cons & .0053888 & .0032002 & -8.80 & 0.000 & $\begin{array}{l}.0016788 \\
\end{array}$ & $\begin{array}{l}1.860408 \\
.0172975\end{array}$ \\
\hline
\end{tabular}

Wte: Variances scaled within each stage to handle strata with a single

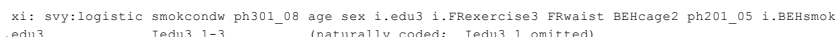
i.edu3 1 - FRexercise3

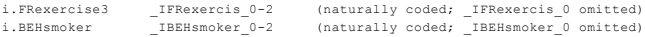

(running logistic on estimation sample)

Survey: Logistic regression

$\begin{array}{llrlrl}\text { Number of strata } & = & 3 & & \text { Number of obs } & =5,176 \\ \text { Number of PSUs } & = & \text { Population size } & =735,169.58 \\ & \text { Design df } & =618 \\ & & & \end{array}$

$\begin{array}{ll}\text { F }(12, \quad 607) & =27.77 \\ \text { Prob }>\text { F } & =0.0000\end{array}$

\begin{tabular}{|c|c|c|c|c|c|c|}
\hline smokcondw & odds Ratio & $\begin{array}{l}\text { Linearized } \\
\text { Std. Err. }\end{array}$ & t & $P>|t|$ & [95\% conf. & Interva1] \\
\hline 1 1_08 & 2.064727 & .5696788 & 2.63 & 0.009 & 1.20101 & 3.549592 \\
\hline & 1.060348 & .00548 & 11.34 & & & 1.071164 \\
\hline & .6715011 & .0660054 & -4.05 & 0.000 & .5536221 & .8144792 \\
\hline - Iedu3_ ${ }_{2}^{2}$ & & .0809291 & -2.28 & & .6481688 & \\
\hline Iedu $3_{-}^{-3}$ & .6655733 & & & 0.001 & .5293153 & .8369072 \\
\hline - IFRexercis $_{-1}{ }^{\text {If }}$ & $\begin{array}{l}.937584 \\
570642\end{array}$ & .0954633 & -0.63 & 0.527 & $\begin{array}{l}.7676658 \\
.45953939\end{array}$ & $\begin{array}{l}1.145113 \\
705522\end{array}$ \\
\hline - IFRexercis_2 $^{\text {Iforais }}$ & & & -5.09 & 0.000 & .4595939 & .7085522 \\
\hline FRwaist & 1.008449 & .0037159 & 2.28 & 0.023 & 1.001178 & 1.015772 \\
\hline $\begin{array}{l}\text { BEHcage2 } \\
\text { ph201 } 05\end{array}$ & $\begin{array}{r}7914049 \\
i .360076\end{array}$ & $\begin{array}{l}.116748 \\
.2128 B\end{array}$ & $\begin{array}{r}-1.59 \\
1.98\end{array}$ & 0.113 & $\begin{array}{r}5923365 \\
.1 .002465\end{array}$ & $\begin{array}{l}1.057339 \\
1.85257\end{array}$ \\
\hline _ IBEHsmoker_1 & $\begin{array}{l}1.754968 \\
1.758\end{array}$ & .16 & $\begin{array}{l}1.98 \\
6.12\end{array}$ & $\begin{array}{l}0.048 \\
0.000\end{array}$ & $\begin{array}{l}1.002465 \\
1.465158\end{array}$ & $\begin{array}{l}1.845257 \\
2.102103\end{array}$ \\
\hline${ }_{-}$IBEHsmoker-2 ${ }^{2}$ & & & 4.23 & 0.0 & & 2.252545 \\
\hline$e_{-\operatorname{cons} s}$ & .0032641 & .0019648 & -9.51 & 0.000 & .0010009 & .0106449 \\
\hline
\end{tabular}

Note: Variances scaled within each stage to handle strata with a single

sampling unit.

. xi: svy: Logistic smokcondw SUorMHprob age sex i.edu3 i. FRexercise3 FRwaist BEHcage2 ph201_05 $\begin{array}{lll}\text { i.edu3 } & \text { Iedu3_1-3 } & \text { (naturally coded; } \\ \text { i.FRexercise3 } & \text { - Iedu3 } 1 \text { omitted) } \\ \text { - IFRexercis_0-2 } & \text { (naturally coded; } & \text { IFRexercis_o omitted }\end{array}$ (running logistic on estimation sample)

Survey: Logistic regression

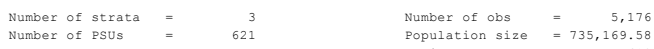
$\begin{array}{rlr}\text { Design df } & =618 \\ \text { Fi } 10, \quad 609) & =28.32\end{array}$

\begin{tabular}{|c|c|c|c|c|c|c|}
\hline smokcondw & odds Ratio & $\begin{array}{l}\text { Linearized } \\
\text { Std. Err. }\end{array}$ & $\mathrm{t}$ & $P>|t|$ & [95음 Conf. & Interva1] \\
\hline SUorMHprob & 1.352862 & .1871792 & 2.18 & 0.029 & 1.030984 & 1.775232 \\
\hline & & & 11.20 & & & 1.070544 \\
\hline & .6013963 & .057782 & -5.29 & 0.000 & .497986 & .7262806 \\
\hline _Iedu3_2 ${ }^{2}$ & .7660956 & . 0775 & -2.63 & 0.009 & & 32 \\
\hline - Iedu3_33 & .6352288 & .0733 & & 0.000 & & .7968267 \\
\hline${ }_{-}^{\text {IFRexercis_ }}{ }^{1}$ & .9353498 & .0949836 & -0.66 & 0.511 & .7662421 & 1.141779 \\
\hline - IFRexercis_2 2 & & .0628372 & & 0.000 & .4601945 & .7089195 \\
\hline $\begin{array}{l}\text { FRwaist } \\
\text { BEHcage2 }\end{array}$ & 1.008633 & .003723 & 2.33 & 0.020 & 1.001348 & $\begin{array}{l}1.015971 \\
1.182668\end{array}$ \\
\hline ph201_05 & $\begin{array}{r}.8885526 \\
1.368528\end{array}$ & $\begin{array}{l}.129375 \\
.2095017\end{array}$ & $\begin{array}{r}-0.81 \\
2.05\end{array}$ & $\begin{array}{l}0.047 \\
0.041\end{array}$ & $\begin{array}{l}.6675801 \\
1.013191\end{array}$ & $\begin{array}{l}1.182668 \\
1.848485\end{array}$ \\
\hline _cons & .0054672 & .0032594 & -8.74 & 0.000 & .0016956 & .0176286 \\
\hline
\end{tabular}

Variances scal
sampling unit.

xi: svy: logistic smokcondw SUorMHprob age sex i.edu3 i. FRexercise3 FRwaist BEHcage2 ph201_05 i.BEHsn i.eduserise 3 (naturally coded:

i. BEHsmoker _IBEHsmoker_0-2 (naturally coded; _IBEHsmoker_o omitted)

(running logistic on estimation sample)

Survey: Logistic regression

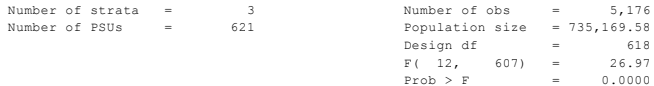

\begin{tabular}{|c|c|c|c|c|c|c|}
\hline smokcondw & Odds Ratio & $\begin{array}{l}\text { Linearized } \\
\text { Std. Err. }\end{array}$ & $t$ & $P>|t|$ & [95\% Conf. & Interva1] \\
\hline SUorMHprob & 1.300407 & . 1781703 & 1.92 & 0.056 & .9936333 & 1.701893 \\
\hline age & 1.060717 & .005504 & 11.36 & 0.000 & & 1.071581 \\
\hline & & .064 & -4.31 & 0.000 & .541 & \\
\hline $\begin{array}{l}\text { - Iedu3 }-2 \\
\text { Iedu3 } 3 \\
\text { Int }\end{array}$ & $\begin{array}{r}.7907759 \\
660569 \\
.\end{array}$ & .0806052 & $\begin{array}{l}-2.30 \\
-3.55\end{array}$ & 0.022 & $\begin{array}{l}.6473195 \\
5251808\end{array}$ & $\begin{array}{l}.9660246 \\
8308491\end{array}$ \\
\hline $\begin{array}{l}\text { - Iedu3 }{ }_{-3}^{3} \\
\text { IFRexcis }\end{array}$ & $\begin{array}{l}.66006499 \\
.9390585\end{array}$ & $\begin{array}{l}.0771472 \\
.0953003\end{array}$ & 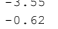 & $\begin{array}{l}0.000 \\
0.536\end{array}$ & $\begin{array}{l}.5251808 \\
.7693766\end{array}$ & $\begin{array}{l}.8808491 \\
1.146163\end{array}$ \\
\hline IfRexercis_2 & & .06 & -5.04 & & & .7129988 \\
\hline & 1.008 & .003 & 2.25 & 0.025 & 1.00 & 1.015608 \\
\hline tage 2 & .8039634 & .1178 & -1.49 & 0.137 & .602 & 1.07218 \\
\hline $\begin{array}{l}\text { Ph201_05 } \\
\text { Hhmoker }\end{array}$ & & .2104 & 1.93 & & & 1.83 \\
\hline $\begin{array}{l}\text { Hsmokere } 1 \\
\text { Hsmoker } 2\end{array}$ & $\begin{array}{l}1.756687 \\
1.75181\end{array}$ & .161172 & 6.14 & 0.000 & $\begin{array}{l}1.467051 \\
1.3507\end{array}$ & $\begin{array}{l}2.103504 \\
\end{array}$ \\
\hline $\begin{array}{l}{ }^{\text {IBEHSmoker }}{ }^{2} \\
\text { cons }\end{array}$ & $\begin{array}{l}1.751381 \\
.0033034\end{array}$ & $\begin{array}{l}.22801 \\
.0019902\end{array}$ & $\begin{array}{r}4.30 \\
-9.48\end{array}$ & $\begin{array}{l}0.000 \\
0.000\end{array}$ & $\begin{array}{l}1.35627 \\
.0010119\end{array}$ & $\begin{array}{l}2.2615595 \\
.0107843\end{array}$ \\
\hline
\end{tabular}

Variances sca
sampling unit. 


\section{Appendix D}

\section{Interaction effects without High Cholesterol}

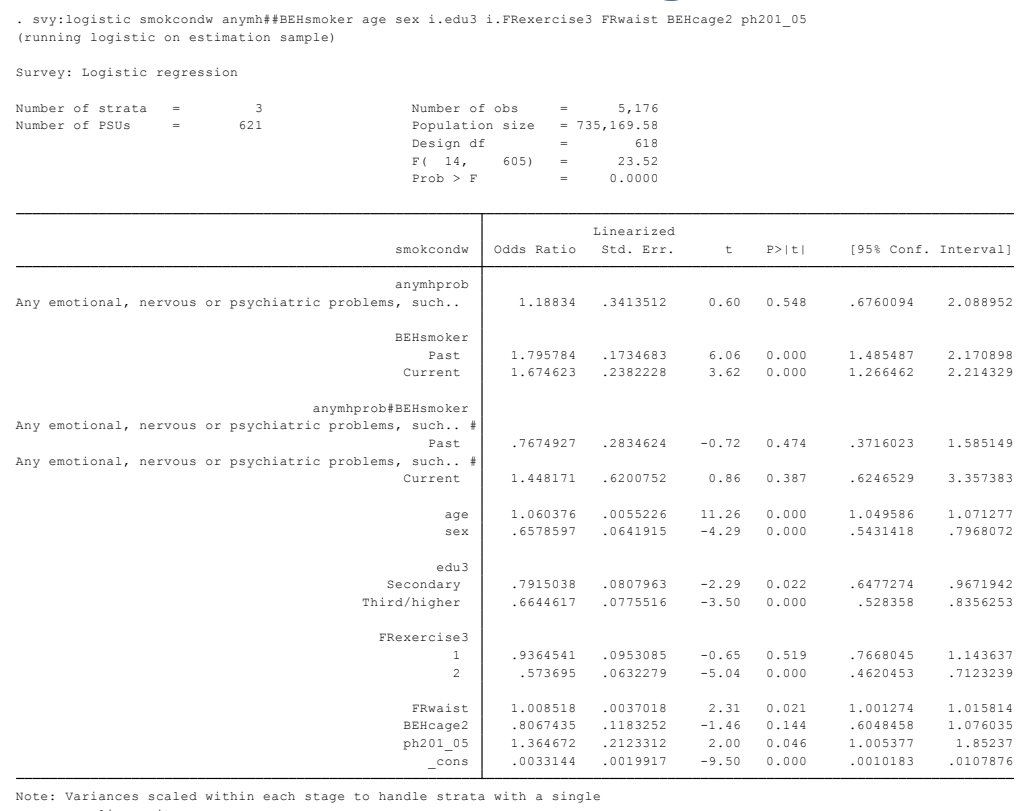

\begin{tabular}{|c|c|c|c|c|c|c|}
\hline $\begin{array}{l}\text { Number of strata }= \\
\text { Number of PSUs }\end{array}$ & $\begin{array}{r}3 \\
621\end{array}$ & & $\begin{array}{l}\text { Number of } \\
\text { Populatio } \\
\text { Design df } \\
\text { F( 14, } \\
\text { Prob > F }\end{array}$ & $\begin{array}{l}\text { obs } \\
\text { size } \\
6055\end{array}$ & $\begin{array}{lr}= & 5,176 \\
= & 735,169.58 \\
= & 618 \\
= & 23.40 \\
& =0.0000\end{array}$ & \\
\hline smokcondw & Odds Ratio & $\begin{array}{l}\text { Linearized } \\
\text { Std. Err. }\end{array}$ & t & $P>|t|$ & [95: Conf. & Interva1] \\
\hline 1. SRpsychmeduse & 1.157096 & .2947086 & 0.57 & 0.567 & .7016907 & 1.908065 \\
\hline $\begin{array}{c}\text { BEHsmoker } \\
\text { Past } \\
\text { Current }\end{array}$ & $\begin{array}{l}1.711713 \\
1.615377\end{array}$ & $\begin{array}{l}.1653646 \\
.2374722\end{array}$ & $\begin{array}{l}5.56 \\
3.26\end{array}$ & $\begin{array}{l}0.000 \\
0.001\end{array}$ & $\begin{array}{l}1.415915 \\
1.210307\end{array}$ & $\begin{array}{l}2.069307 \\
2.156017\end{array}$ \\
\hline $\begin{array}{r}\text { SRpsychmeduse\#BEHsmoker } \\
1 \text { 1\#ast } \\
1 \text { - Current }\end{array}$ & $\begin{array}{l}1.278069 \\
1.648508\end{array}$ & $\begin{array}{l}.4094863 \\
.6345066\end{array}$ & $\begin{array}{l}0.77 \\
1.30\end{array}$ & $\begin{array}{l}0.444 \\
0.195\end{array}$ & $\begin{array}{l}.6812381 \\
.7741456\end{array}$ & $\begin{array}{l}2.397783 \\
3.510422\end{array}$ \\
\hline $\begin{array}{l}\text { age } \\
\text { sex }\end{array}$ & $\begin{array}{l}1.059847 \\
.6465358\end{array}$ & $\begin{array}{l}.0054565 \\
.0639954\end{array}$ & $\begin{array}{l}11.29 \\
-4.45\end{array}$ & $\begin{array}{l}0.000 \\
0.000\end{array}$ & $\begin{array}{l}1.049186 \\
.5332922\end{array}$ & $\begin{array}{l}1.070617 \\
.7838266\end{array}$ \\
\hline $\begin{array}{c}\text { edu3 } \\
\text { Secondary } \\
\text { Third/higher }\end{array}$ & $\begin{array}{l}.8022392 \\
.674168\end{array}$ & $\begin{array}{l}.0826634 \\
.0792226\end{array}$ & $\begin{array}{l}-2.14 \\
-3.36\end{array}$ & $\begin{array}{l}0.033 \\
0.001\end{array}$ & $\begin{array}{l}.6552745 \\
.5352365\end{array}$ & $\begin{array}{l}.9821651 \\
.8491619\end{array}$ \\
\hline $\begin{array}{c}\text { FRexercise } 3 \\
1 \\
2\end{array}$ & $\begin{array}{l}.9502328 \\
.5804056\end{array}$ & $\begin{array}{l}.0967789 \\
.0640517\end{array}$ & $\begin{array}{l}-0.50 \\
-4.93\end{array}$ & $\begin{array}{l}0.616 \\
0.000\end{array}$ & $\begin{array}{l}.7779775 \\
.4673169\end{array}$ & $\begin{array}{l}1.160628 \\
.7208613\end{array}$ \\
\hline $\begin{array}{r}\text { FRwaist } \\
\text { BEHcage2 }\end{array}$ & $\begin{array}{l}1.00 \\
.809\end{array}$ & & $\begin{array}{r}2.21 \\
-1.45\end{array}$ & $\begin{array}{l}0.028 \\
0.146\end{array}$ & & \\
\hline $\begin{array}{r}\text { ph201_ } 05 \\
\text { cons }\end{array}$ & $\begin{array}{l}1.325562 \\
.0035896\end{array}$ & $\begin{array}{l}.2058405 \\
.0021633\end{array}$ & $\begin{array}{r}1.81 \\
-9.34\end{array}$ & $\begin{array}{l}0.070 \\
0.000\end{array}$ & $\begin{array}{l}.9771501 \\
.0010991\end{array}$ & $\begin{array}{r}1.798202 \\
0117229\end{array}$ \\
\hline
\end{tabular}

e: Variances sca
sampling unit. 
. svy:1ogistic smokcondw SRmed_pr\#\#BEHsmoker age sex i.edu3 i.FRexercise3 ERwaist BEHcage2 ph201_05 gistic on estimation sample)

Survey: Logistic regression

\begin{tabular}{|c|c|c|c|c|c|c|}
\hline $\begin{array}{ll}\text { Number of strata } & = \\
\text { Number of PSUS } & =\end{array}$ & $\begin{array}{r}3 \\
621\end{array}$ & & $\begin{array}{l}\text { Numbe } \\
\text { Popu1 } \\
\text { Desig } \\
\text { F } 11 \\
\text { Prob }\end{array}$ & $\begin{array}{l}\text { of obs } \\
\text { on size } \\
\text { df size } \\
605)\end{array}$ & $\begin{array}{l}= \\
=735,169 . \\
= \\
= \\
=\end{array}$ & \\
\hline smokcondw & Odds Ratio & $\begin{array}{l}\text { Linearized } \\
\text { Std. Err. }\end{array}$ & t & $P>|t|$ & [95: Conf. & Interva1] \\
\hline 1. SRmed_prob & .4143275 & .2231586 & -1.64 & 0.102 & .1438744 & 1.193175 \\
\hline $\begin{array}{c}\text { BEHsmoker } \\
\text { Past }\end{array}$ & 1.711965 & .1611716 & 5.71 & 0.000 & 1.42299 & 2.059623 \\
\hline Current & 1.704207 & .2305622 & 3.94 & 0.000 & 1.306584 & 2.222836 \\
\hline $\begin{array}{c}\text { SRmed_prob\#\#EHsmoker } \\
\text { 1:Past }\end{array}$ & & & & & & \\
\hline $\begin{array}{r}\text { 1*Past } \\
1 \text { 1*Current }\end{array}$ & $\begin{array}{l}2.788676 \\
3.459546\end{array}$ & $\begin{array}{l}1.757905 \\
2.374841\end{array}$ & $\begin{array}{l}1.63 \\
1.81\end{array}$ & $\begin{array}{l}0.104 \\
0.071\end{array}$ & $\begin{array}{l}.80866955 \\
.8985793\end{array}$ & $\begin{array}{l}9.616676 \\
13.31931\end{array}$ \\
\hline $\begin{array}{l}\text { age } \\
\text { sex }\end{array}$ & $\begin{array}{l}1.060509 \\
.6600092\end{array}$ & $\begin{array}{l}.0055068 \\
.0647436\end{array}$ & $\begin{array}{l}11.31 \\
-4.24\end{array}$ & $\begin{array}{l}0.000 \\
0.000\end{array}$ & $\begin{array}{l}1.04975 \\
.5443617\end{array}$ & $\begin{array}{l}1.071379 \\
.8002257\end{array}$ \\
\hline edu3 & & & & & & \\
\hline $\begin{array}{r}\text { Secondary } \\
\text { Third/higher }\end{array}$ & $\begin{array}{l}.7919887 \\
.6654237\end{array}$ & $\begin{array}{l}.0808575 \\
.0777342\end{array}$ & $\begin{array}{l}-2.28 \\
-3.49\end{array}$ & $\begin{array}{l}0.023 \\
0.001\end{array}$ & $\begin{array}{l}.6489055 \\
.5290133\end{array}$ & $\begin{array}{l}.9678749 \\
.8370088\end{array}$ \\
\hline $\begin{array}{c}\text { FRexercise } 3 \\
1\end{array}$ & .9395112 & .0955518 & -0.61 & 0.540 & .7694169 & 1.147208 \\
\hline & & 0037 & 2.29 & & 1 . 001215 & \\
\hline BEHcage2 & .8251179 & .1202514 & -1.32 & 0.188 & .6197547 & $\begin{array}{l}1.01381 \\
1.098531\end{array}$ \\
\hline ph201_05 & 1.350999 & .2110519 & 1.93 & 0.055 & .994077 & 1.836073 \\
\hline cons & .0033901 & .0020338 & -9.48 & 0.000 & .0010436 & .0110121 \\
\hline
\end{tabular}

: variances so

(running logistic smokcondw SRmedoRpro\#\#BE

Survey: Logistic regressio

$\begin{array}{llr}\text { Number of strata } & = & 3 \\ \text { Number of PSUs } & = & 621\end{array}$

$\begin{aligned} \text { Number of obs } & =5,176 \\ \text { Population size } & =735,169.58\end{aligned}$

E( 14, 605) $=24.0$

\begin{tabular}{|c|c|c|c|c|c|c|}
\hline smokcondw & Odds Ratio & $\begin{array}{l}\text { Linearized } \\
\text { Std. Erx. }\end{array}$ & t & $P>|t|$ & [95: Conf & Interval] \\
\hline 1.SRmedoRprob & 1.472727 & .3050825 & 1.87 & 0.062 & .9804957 & 2.212069 \\
\hline BEHsmoker & & & & & & \\
\hline $\begin{array}{r}\text { Past } \\
\text { Current }\end{array}$ & $\begin{array}{l}1.801313 \\
1.571302\end{array}$ & $\begin{array}{l}.1788483 \\
.2447424\end{array}$ & $\begin{array}{l}5.93 \\
2.90\end{array}$ & $\begin{array}{l}0.000 \\
0.004\end{array}$ & $\begin{array}{l}1.482209 \\
1.157226\end{array}$ & $\begin{array}{l}2.189117 \\
2.13354\end{array}$ \\
\hline SRme doRprob\#BEH smoker & & & & & & \\
\hline $\begin{array}{l}\text { 14 Past } \\
\text { 1" Current }\end{array}$ & $\begin{array}{l}.8330579 \\
1.41644\end{array}$ & $\begin{array}{l}.2253659 \\
.4675189\end{array}$ & $\begin{array}{r}-0.68 \\
1.04\end{array}$ & $\begin{array}{l}0.500 \\
0.298\end{array}$ & $\begin{array}{l}.4897214 \\
.7366562\end{array}$ & $\begin{array}{l}1.417103 \\
2.705119\end{array}$ \\
\hline $\begin{array}{l}\text { age } \\
\text { sex }\end{array}$ & $\begin{array}{r}1.060349 \\
6644594\end{array}$ & .0054924 & $\begin{array}{l}11.31 \\
-4.48\end{array}$ & 0.000 & $\begin{array}{l}1.049617 \\
5317783\end{array}$ & $\begin{array}{l}1.07119 \\
.7813432\end{array}$ \\
\hline & & & & & & \\
\hline $\begin{array}{l}\text { Secondary } \\
\text { serat }\end{array}$ & .8050038 & 082776 & -2.11 & 0.035 & 6578089 & $.985135 t \mathrm{t} \mathrm{l}$ \\
\hline Third/higher & .672192 & .0787211 & $\begin{array}{r}-3.11 \\
-3.39\end{array}$ & 0.001 & .5340878 & .846007 \\
\hline FRexercise 3 & & & & & & \\
\hline$\frac{1}{2}$ & .9511481 & .0973017 & -0.49 & 0.625 & .7780367 & 1.16277 \\
\hline haist & 1.00 & 003 & 2 & 8,023 & & \\
\hline BEHcage 2 & .7936025 & .1155667 & $\begin{array}{r}-1.59 \\
-1.59\end{array}$ & 0.113 & $\begin{array}{r}.5962184 \\
\end{array}$ & 1.05633 \\
\hline ph201_05 & 1.324806 & .2054783 & 1.81 & 0.070 & .976948 & 1.79652 \\
\hline -cons & .0032417 & .0019559 & -9.50 & 0.000 & .0009912 & .0106019 \\
\hline
\end{tabular}

Note: Variances scaled within each stage to handle strata with a single 
- svy:1ogistic smokcondw ph301_08\#\#BEHsmoker age sex i.edu3 i.ERexercise3 FRwaist BEHcage2 ph201_0 gistic on estimation sample)

Survey: Logistic regression

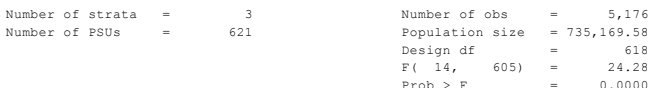

\begin{tabular}{|c|c|c|c|c|c|c|}
\hline smokcondw & Odds Ratio & $\begin{array}{l}\text { Linearized } \\
\text { Std. Err. }\end{array}$ & t & $P>|t|$ & [958 Conf. & Interval] \\
\hline $\begin{array}{l}\text { ph301_08 } \\
\text { Alcohal or substance abuse }\end{array}$ & .9953103 & 1.059573 & -0.00 & 0.996 & .1230327 & 8.051866 \\
\hline $\begin{array}{c}\text { BEHsmoker } \\
\text { Past } \\
\text { Current }\end{array}$ & $\begin{array}{l}1.746209 \\
1.712074\end{array}$ & $\begin{array}{r}.1612341 \\
.23467\end{array}$ & $\begin{array}{l}6.04 \\
3.92\end{array}$ & $\begin{array}{l}0.000 \\
0.000\end{array}$ & $\begin{array}{l}1.456623 \\
1.308041\end{array}$ & $\begin{array}{l}2.093366 \\
2.240906\end{array}$ \\
\hline $\begin{array}{l}\text { ph301_08\#BEHsmoker } \\
\text { Alcohal or substance abuse\#past } \\
\text { A1cohal or substance abuse\#Current }\end{array}$ & $\begin{array}{l}2.054481 \\
2.526982\end{array}$ & $\begin{array}{l}2.171275 \\
2.914865\end{array}$ & $\begin{array}{l}0.68 \\
0.80\end{array}$ & $\begin{array}{l}0.496 \\
0.422\end{array}$ & $\begin{array}{l}.2578374 \\
.2623114\end{array}$ & $\begin{array}{l}16.37037 \\
24.34372\end{array}$ \\
\hline $\begin{array}{l}\text { age } \\
\text { sex }\end{array}$ & $\begin{array}{r}1.06036 \\
.6725472\end{array}$ & $\begin{array}{l}.0054898 \\
.0661322\end{array}$ & $\begin{array}{r}11.32 \\
-4.03\end{array}$ & $\begin{array}{l}0.000 \\
0.0000\end{array}$ & $\begin{array}{l}1.049633 \\
.5544458\end{array}$ & $\begin{array}{l}1.071196 \\
.8158052\end{array}$ \\
\hline $\begin{array}{r}\text { edus } \\
\text { Secondary } \\
\text { Third/higher }\end{array}$ & $\begin{array}{l}.7928453 \\
.6671965\end{array}$ & $\begin{array}{l}.0809493 \\
.077867\end{array}$ & $\begin{array}{l}-2.27 \\
-3.47\end{array}$ & $\begin{array}{l}0.023 \\
0.001\end{array}$ & $\begin{array}{l}.6487994 \\
.5305387\end{array}$ & $\begin{array}{l}.9688722 \\
.8390551\end{array}$ \\
\hline $\begin{array}{r}\text { FRexercise } 3 \\
1 \\
2\end{array}$ & $\begin{array}{l}.9378614 \\
.5725097\end{array}$ & $\begin{array}{l}.095481 \\
.0632547\end{array}$ & $\begin{array}{l}-0.63 \\
-5.05\end{array}$ & $\begin{array}{l}0.529 \\
0.000\end{array}$ & $\begin{array}{l}.7679099 \\
.4608419\end{array}$ & $\begin{array}{l}1.145426 \\
.7112361\end{array}$ \\
\hline ERwaist & 1.008465 & .0037195 & 2.29 & 0.023 & 1.001187 & 1.015796 \\
\hline & 1.362 & .211 & 1.99 & 0.047 & 1.003922 & 1.848402 \\
\hline -cons & .0032586 & .0019619 & -9.51 & 0.000 & .0009989 & .0106299 \\
\hline
\end{tabular}

Note: Variances scaled within each stage to handle strata with a single

mpling unit.

. svy: 10 ogistic smokcondw SUorMHprob\#\#BEHsmoker age sex i.edu3 i. FRexercise3 FRwaist BEHcage2 ph201_05 Survey: Logistic regression

Number of obs $=5,176$

Design df $\quad=618$

$\begin{aligned}\text { Fit } 14, \quad 605) & =23.77 \\ \text { Prob }>F & \end{aligned}$

\begin{tabular}{|c|c|c|c|c|c|c|}
\hline smokcondw & odds Ratio & $\begin{array}{l}\text { Linearized } \\
\text { Std. Erx. }\end{array}$ & t & $P>|t|$ & [95: Conf & Interva1] \\
\hline 1. SUorMHprob & 1.208155 & .3381078 & 0.68 & 0.499 & .6973362 & 2.093162 \\
\hline BEHsmoker & & & & & & \\
\hline $\begin{array}{l}\text { Past } \\
\text { Current }\end{array}$ & $\begin{array}{l}1.785904 \\
1.611281\end{array}$ & $\begin{array}{l}.1733871 \\
.2374574\end{array}$ & $\begin{array}{l}5.97 \\
3.24\end{array}$ & $\begin{array}{l}0.000 \\
0.001\end{array}$ & $\begin{array}{l}1.475896 \\
1.206374\end{array}$ & $\begin{array}{l}2.161028 \\
2.152091\end{array}$ \\
\hline \multirow{2}{*}{\multicolumn{7}{|c|}{$\begin{array}{c}\text { suorMHprob \# BEHsmoker } \\
1 \neq \text { Past }\end{array}$}} \\
\hline & .8568521 & .2941629 & -0.45 & 0.653 & .4366258 & 1.681521 \\
\hline 1\%Current & 1.64961 & .66553 & 1.24 & 0.215 & .7469519 & 3.643089 \\
\hline age & 1.060493 & .0055244 & 11.27 & 0.000 & 1.049699 & 1.071398 \\
\hline sex & .6588418 & .0644744 & -4.26 & 0.000 & .5436494 & .798442 \\
\hline $\begin{array}{r}\text { edu3 } 3 \\
\text { Secondary }\end{array}$ & & & & & & \\
\hline $\begin{array}{l}\text { Secondary } \\
\text { Third/higher }\end{array}$ & $\begin{array}{l}.7921048 \\
.6628534\end{array}$ & $\begin{array}{l}.0773579 \\
.09\end{array}$ & $\begin{array}{l}-2.29 \\
-3.52\end{array}$ & 0.000 & $\begin{array}{l}.042730886 \\
.527086\end{array}$ & $\begin{array}{l}.9677607 \\
.8335879\end{array}$ \\
\hline \multicolumn{7}{|l|}{ FRexercise 3} \\
\hline 2 & $\begin{array}{l}.936184 \\
.5755076\end{array}$ & $\begin{array}{l}.0951911 \\
.0633903\end{array}$ & $\begin{array}{l}-0.65 \\
-5.02\end{array}$ & $\begin{array}{l}0.517 \\
0.000\end{array}$ & $\begin{array}{l}.7667279 \\
.4635643\end{array}$ & $\begin{array}{l}1.1143092 \\
.7144834\end{array}$ \\
\hline & 1.00849 & .0037048 & 2.30 & 0.022 & 1.001241 & $1.01 \mathrm{Y}$ \\
\hline BEHcage 2 & .7889383 & .1170974 & -1.60 & 0.111 & .5894628 & 1.055917 \\
\hline $\begin{array}{r}\text { ph201_05 } \\
\text { cons }\end{array}$ & $\begin{array}{l}1.360917 \\
.003868\end{array}$ & $\begin{array}{l}.2120385 \\
.0019757\end{array}$ & $\begin{array}{r}1.98 \\
-9.51\end{array}$ & $\begin{array}{l}0.048 \\
0.000\end{array}$ & $\begin{array}{l}1.002189 \\
.00110095\end{array}$ & $\begin{array}{l}1.848051 \\
.0107015\end{array}$ \\
\hline
\end{tabular}

ote: Variances scaled within each stage to handle strata with a single
sampling unit. 
